\title{
Succinate causes pathological cardiomyocyte hypertrophy through GPR91 activation
}

\author{
Carla J Aguiar', João A Rocha-Franco', Pedro A Sousa', Anderson K Santos², Marina Ladeira', \\ Cibele Rocha-Resende ${ }^{1}$, Luiz O Ladeira ${ }^{3}$, Rodrigo R Resende ${ }^{2}$, Fernando A Botoni ${ }^{4}$, Marcos Barrouin Melo ${ }^{1}$, \\ Cristiano X Lima ${ }^{4}$, José M Carballido ${ }^{5}$, Thiago M Cunha ${ }^{6}$, Gustavo B Menezes ${ }^{7}$, Silvia Guatimosim ${ }^{1}$ and \\ M Fatima Leite ${ }^{1 *}$
}

\begin{abstract}
Background: Succinate is an intermediate of the citric acid cycle as well as an extracellular circulating molecule, whose receptor, G protein-coupled receptor-91 (GPR91), was recently identified and characterized in several tissues, including heart. Because some pathological conditions such as ischemia increase succinate blood levels, we investigated the role of this metabolite during a heart ischemic event, using human and rodent models.

Results: We found that succinate causes cardiac hypertrophy in a GPR91 dependent manner. GPR91 activation triggers the phosphorylation of extracellular signal-regulated kinase 1/2 (ERK1/2), the expression of calcium/calmodulin dependent protein kinase II (CaMKII $)$ and the translocation of histone deacetylase 5 (HDAC5) into the cytoplasm, which are hypertrophic-signaling events. Furthermore, we found that serum levels of succinate are increased in patients with cardiac hypertrophy associated with acute and chronic ischemic diseases.
\end{abstract}

Conclusions: These results show for the first time that succinate plays an important role in cardiomyocyte hypertrophy through GPR91 activation, and extend our understanding of how ischemia can induce hypertrophic cardiomyopathy.

Keywords: Succinate, Cardiomyocyte, Hypertrophy

\section{Background}

Cardiac hypertrophy is an adaptive response to biomechanical overload or extracellular stimuli and it is associated with augmented risk of heart failure and sudden death [1-3]. At the molecular level, cardiomyocyte hypertrophy is characterized by reinduction of the so-called fetal gene program, leading to upregulation of genes encoding atrial and brain natriuretic peptides, $\beta$-myosin heavy chain and skeletal $\alpha$ actin [4]. At the cellular level, increased cell-size and enhanced protein synthesis are the prominent characteristics [5]. Several pathologies including hypertension and ischemic diseases are known to cause hypertrophy [6-10]. However, the exact mechanism is poorly understood [11-13].

Succinate is an important intermediate metabolite of the citric acid cycle and in conditions linked with insufficient blood supply, such as ischemia, succinate blood

\footnotetext{
* Correspondence: leitemd@ufmg.br

${ }^{1}$ Department of Physiology and Biophysics, Federal University of Minas

Gerais, Av. Antônio Carlos 6627, Belo Horizonte MG - CEP: 31270-901, Brazil

Full list of author information is available at the end of the article
}

levels may rise $[14,15]$. The formation of succinate during ischemia occurs in different ways: in the presence or in the absence of alpha-ketoglutarate (anaplerotic reaction) $[16,17]$. In the reaction in which alpha-ketoglutarate is present, the reactive oxygen species (ROS) that are increased during ischemia promote decarboxylation of alphaketoglutarate, resulting in a non-enzymatic formation of succinate that can occur both in the mitochondria and in the cytosol [17]. In the absence of alpha-ketoglutarate, the substrates that form succinate are especially amino acids glutamine and alanine. These amino acids provide one carbon skeleton for the formation of succinate [14,17-20].

Besides succinate crucial role in energy metabolism, it also acts as a signaling molecule by binding to and activating its specific G-protein coupled receptor (GPCR), known as GPR91 [21]. Signaling pathways triggered by GPR91 include increases in intracellular $\mathrm{Ca}^{2+}$ and cAMP, as well as activation of mitogen-activated protein kinases and extracellular signal-regulated kinases-1/2 (MAPK-ERK1/2) [21-23]. GPR91 was first reported in kidney [21], but 
more recently it was detected in other tissues, including cardiac muscle [15,21,22]. In cardiomyocytes, succinate modulates global $\mathrm{Ca}^{2+}$ transients and cell viability through a PKA-dependent pathway. In this study, we show for the first time that increased levels of succinate due to ischemia cause cardiac hypertrophy via GPR91 activation.

\section{Results \\ Activation of GPR91 by succinate causes cardiomyocyte hypertrophy likely due to long-term blood pressure counter regulatory mechanisms}

Extracellular accumulation of up to millimolar levels of succinate is observed in pathophysiological conditions, such as ischemia $[14,15,21]$. Moreover, there is a close correlation between myocardial ischemia and hypertrophic cardiomyopathy $[24,25]$. To investigate whether succinate causes cardiac hypertrophy, a succinate dose of $0.066 \mathrm{mg} / \mathrm{kg}$, equivalent to that observed during ischemic events [15], was administered intravenously to rats, once a day, for 5 consecutive days. By using perfusedfixed hearts from PBS (control) and succinate treated animals, we evaluated changes in cardiomyocyte width from left cardiac ventricle sections in longitudinal orientation. Morphometric analysis showed a significant increase in average myocyte width of groups treated with succinate compared to controls, $(12 \pm 0.10 \mu \mathrm{m}$ in control $v s 14.7 \pm$ $0.10 \mu \mathrm{m}$ in succinate treated animals, $\mathrm{p}<0.001$ ), (Figure $1 \mathrm{~A}$ ). We also observed a significant increase in myocyte nuclear diameter in succinate treated groups $(4.3 \pm 0.12 \mu \mathrm{m}$ in cardiomyocytes from control animals $v s 5.6 \pm 0.2 \mu \mathrm{m}$ in succinate treated rats, $\mathrm{p}<0.001$ ), (Figure $1 \mathrm{~B}$ ), suggesting that high circulating succinate levels might cause cardiac hypertrophy. This finding was confirmed by evaluating the expression levels of genes expressed during cardiac hypertrophy. We detected upregulation of hypertrophic markers atrial natriuretic peptide (ANP), brain natriuretic peptide (BNP), and $\beta$-myosin heavy chain (MYH7). Moreover we fond a significant increase in $\alpha$-skeletal actin $(\alpha-S k A)$ mRNA levels, a known marker for pathological hypertrophy, in heart samples from succinate treated groups. We observed an increase of $160 \%$ in the expression level of ANP (a.u. $=100$ in control cells vs. $260 \pm 6.5 \%$ in cells from succinate treated rats, $\mathrm{p}<0.001)$, an increase of $175 \%$ in the expression of BNP (a.u. $=100 \%$ in cells from control rats vs $275 \pm 10 \%$ in cells from succinate treated rats, $\mathrm{p}<0.001$ ), an increase of $125 \%$ in the expression of MYH7 (a.u. $=100 \%$ in cells from control rats vs $225 \pm 3 \%$ in cells from succinate treated rats, $\mathrm{p}<0.001)$, and increase of $168 \%$ in the expression level of $\alpha$-SkA (a.u. $=100$ in control cells vs $268 \pm 6.3 \%$ in cells from succinate treated rats, $\mathrm{p}<0.001)$ in freshly isolated adult cardiomyocytes from succinate treated rats when compared to control animals (Figure 1C-F). Succinate is knows to activate the renin angiotensin system (RAS) [21], which can modulate blood pressure [26]. Since sustained increase in blood pressure is know to cause cardiac hypertrophy $[27,28]$, we investigated whether the hypertrophy induced by high levels of succinate in the blood stream was a consequence of succinate triggering changes in the arterial blood pressure. Under our experimental conditions, we found that the mean arterial blood pressure (MAP) level was unaffected after two days of succinate treatment, but slightly increased at day 4, and reverted to normal values on the final day of the experiment (day 3: $101.9 \pm 0.78 \mathrm{mmHg}$ in control rats, $109 \pm 0.42 \mathrm{mmHg}$ in control rats treated with losartan, $102 \pm 1.52 \mathrm{mmHg}$ for succinate-treated rats and $99 \pm$ $3.85 \mathrm{mmHg}$ for rats treated with succinate and losartan, day 4: $101.2 \pm 2.86 \mathrm{mmHg}$ in control rats, $95.82 \pm 1.88 \mathrm{mmHg}$ in control rats treated with losartan, $111.6 \pm 2.60 \mathrm{mmHg}$ in succinate-treated rats and $79.92 \pm 2.48 \mathrm{mmHg}$ in rats treated with succinate and losartan, day 5: $98.8 \pm 2.94 \mathrm{mmHg}$ in control rats, $90.43 \pm 5.2 \mathrm{mmHg}$ in control rats treated with losartan, $105.3 \pm 4.8 \mathrm{mmHg}$ in succinate treated rats, $77.51 \pm 5.79 \mathrm{mmHg}$ in rats treated with succinate and losartan). These variations occurred without any change on the heart rate (Figure 2A-D), even though at the last experimental day, the serum concentration of succinate was significantly higher in treated animals compared to control $(0 \mathrm{mM}$ in control rats $v s 0.9 \pm 0.13 \mathrm{mM}$ in succinate treated rats, $\mathrm{p}<0.001$ ), (Figure $2 \mathrm{E}$ ). We noticed that increases in blood pressure induced by succinate were reverted by losartan, a well-known inhibitor of type I angiotensin-II receptor [29]. Additionally, the consequences of in vivo succinate exposure for cardiac function were further investigated by echocardiography experiment in the presence or absence of losartan. Table 1 shows that succinate increased cardiac output $(52.17 \pm 5$ in control rats $v s 68.03 \pm 2.9$ in succinate rats, $\mathrm{p}<0.05$ ), left ventricular end diastolic volume (LVd: $180 \pm 9.7$ in control rats $v s 245.20 \pm 10.11$ in succinate rats, $\mathrm{p}<0.01$ ), stroke volume (SV: $136.7 \pm 12.63$ in control rats $v s 167.5 \pm 7.34$ in succinate rats, $\mathrm{p}<0.01$ ), and left ventricular chamber dimension, at both systole (LVIDs: $3.02 \pm 0.06$ in control rats $v s 3.96 \pm 0.10, \mathrm{p}<0.01)$ and diastole (LVIDd: $6.15 \pm 0.22$ in control rats vs $6.99 \pm 0.09$, $\mathrm{p}<0.01$ ). Although losartan did not affect most evaluated parameters, it slightly attenuated succinate-induced increase in left ventricular chamber diameter during diastole (LVIDd: $6.99 \pm 0.09$ in succinate rats $v s 6.50 \pm 0.15$ in succinate + losartan, $\mathrm{p}<0.05)$. Real time PCR of hypertrophic markers from these experimental groups showed that losartan partially reverted the re-expression of ANP and MYH7 induced by succinate. We observed a decreased of $110.7 \%$ in the expression level of ANP (a.u. $=304 \pm 4.33 \%$ in rats hearts treated with succinate vs. $193.3 \pm 6.67 \%$ in rats hearts treated with succinate in the presence of losartan, $\mathrm{p}<0.001$ ), and a decreased of $38.7 \%$ in the 


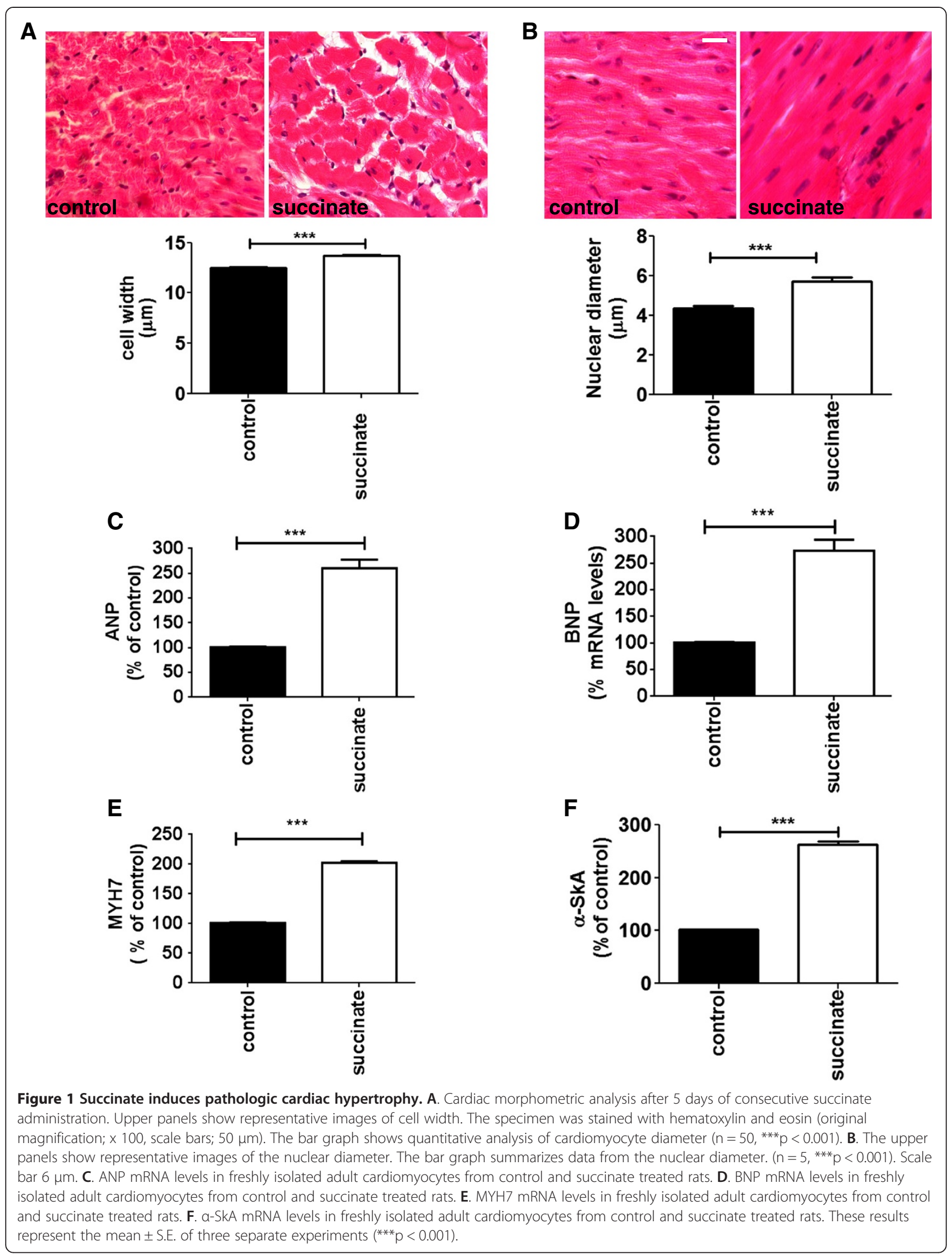


A

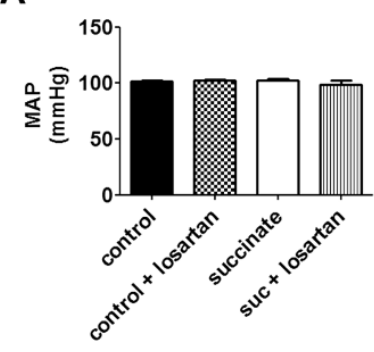

C

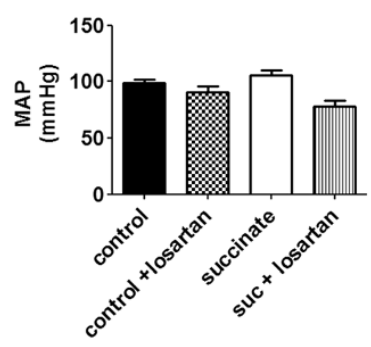

B

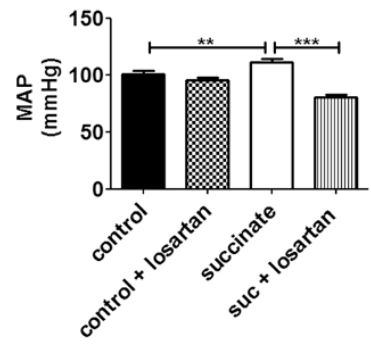

D

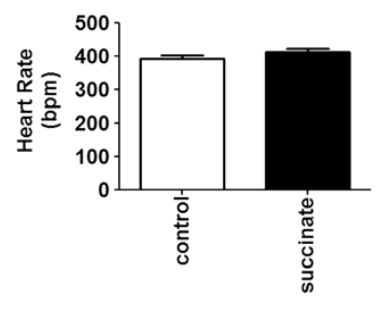

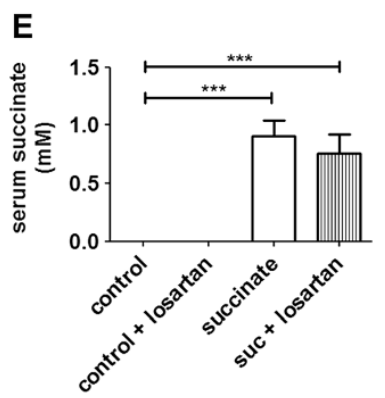

Figure 2 Sustained levels of serum succinate cause increase in blood pressure on day 4 of treatment, but do not affect heart rate throughout the experiment. Medium Arterial Pressure levels in control animals and succinate treated animals, with or without IV injection of losartan on the $3^{\text {rd }}$ day $(\mathbf{A}), 4^{\text {th }}$ day $(\mathbf{B})$ and $5^{\text {th }}$ day of treatment $(\mathbf{C})\left({ }^{* *} p<0.01,{ }^{* * *} p<0.001\right)$. D. Mean heart rate of control and succinate treated rats during the experiment. $\mathbf{E}$. Serum succinate concentration measured on the last day of experiment.

expression of MYH7 (a.u. $=174 \pm 3.05 \%$ in rats hearts treated with succinate vs $135.3 \pm 2.9 \%$ in in rats hearts treated with succinate in the presence of losartan, $\mathrm{p}<0.001$ ), (Additional file 1: Figure S1A-B). Thus, these findings corroborate previous data showing that succinate activates RAS $[21,23,30]$. To address the role of GPR91 on succinate-induced cardiac hypertrophy, we performed echocardiogram using GPR91 knockout (GPR91 KO) mice. Table 2 shows that GPR91-KO mice have no alteration in echocardiographic parameters when compared to wild type. Despite the absence of GPR91, KO mice treated with succinate showed changes in left ventricular ejection fraction (LV-EF $44.33 \pm 0.35$ in wild mice $v s 57.37 \pm 0.77$ in wild mice treated with succinate, $\mathrm{p}<0.05$, and $38.17 \pm 1.4$ in GPR91 KO mice vs $52.9 \pm 4.7$ in GPR91 knockout mice treated with succinate, $\mathrm{p}<0.05$ ), fractional shortening (LV-FS: $21.51 \pm 0.23$ in wild mice $v s 29.86 \pm 0.23$ in wild mice treated with succinate, $\mathrm{p}<0.05$, and $18.05 \pm 0.70$ in GPR91 knockout mice vs 26.14 \pm 2.97 in GPR91 knockout mice treated with succinate, $\mathrm{p}<0.05$ ), and systolic volume (LV-SV: $32.65 \pm 0.65$ in wild mice $v s 22.13 \pm 0.87$ in wild mice treated with succinate, $\mathrm{p}<0.01$, and $31.43 \pm 3.44$ in GPR91 knockout mice vs $17.76 \pm 1.36$ in GPR91 knockout mice treated with succinate, $\mathrm{p}<0.01$ ). Importantly, succinate-induced increase in left ventricular posterior wall (LVPWs: $0.64 \pm 0.09$ in wild mice vs $1.05 \pm 0.07$ in

Table 1 Echocardiographic parameters

\begin{tabular}{|c|c|c|c|c|}
\hline Parameter & Control $(n=6)$ & Control + Losartan $(n=3)$ & Succinate $(n=8)$ & Suc + Losartan $(n=5)$ \\
\hline Cardiac output (mL/min) & $52.17 \pm 5.029$ & $52.67 \pm 4.7$ & $68.03 \pm 2.9^{*}$ & $56.14 \pm 3.12$ \\
\hline LV ejection fraction (\%) & $71.74 \pm 3.02$ & $75.43 \pm 1.78$ & $74.00 \pm 1$ & $71.76 \pm 1.00$ \\
\hline LV fraction shortening (\%) & $40.95 \pm 2.57$ & $45.20 \pm 1.81$ & $43.42 \pm 0.9$ & $41.87 \pm 0.87$ \\
\hline $\operatorname{LVd}(\mu \mathrm{L})$ & $180.00 \pm 9.7$ & $203.90 \pm 8.5$ & $245.20 \pm 10.11^{\#}$ & $209.30 \pm 12.09$ \\
\hline LV systolic volume $(\mu \mathrm{L})$ & $72.98 \pm 6.34$ & $44.64 \pm 7.31$ & $62.70 \pm 7.53$ & $57.06 \pm 3.9$ \\
\hline Stroke volume $(\mu \mathrm{l})$ & $136.70 \pm 12.63$ & $137.20 \pm 12.99$ & $167.50 \pm 7.34^{\#}$ & $142.10 \pm 6.9$ \\
\hline Heart rate (bpm) & $398.00 \pm 9.2$ & $399.40 \pm 10.19$ & $402.90 \pm 7.9$ & $393.60 \pm 17.18$ \\
\hline $\operatorname{LVIDd}(\mathrm{mm})$ & $6.15 \pm 0.22$ & $6.32 \pm 0.11$ & $6.99 \pm 0.09^{\#}$ & $6.50 \pm 0.15^{\&}$ \\
\hline LVIDs (mm) & $3.02 \pm 0.06$ & $3.49 \pm 0.14$ & $3.96 \pm 0.10^{\#}$ & $3.70 \pm 0.10^{*}$ \\
\hline
\end{tabular}

${ }^{*} \mathrm{p}<0.05$ versus control.

$\&_{p}<0.05$ versus succinate.

$\# p<0.01$ versus control. 
Table 2 Echocardiographic parameters

\begin{tabular}{|c|c|c|c|c|}
\hline Parameter & Control $(n=3)$ & Succinate $(n=3)$ & GPR91 $^{-/-}(n=4)$ & GPR91 $1^{-l-}+$ suc $(n=3)$ \\
\hline Cardiac output (mL/min) & $13.09 \pm 1.19$ & $13.02 \pm 0.46$ & $10.64 \pm 0.55$ & $9.18 \pm 1.29$ \\
\hline LV ejection fraction (\%) & $44.33 \pm 0.35$ & $57.37 \pm 0.77^{*}$ & $38.17 \pm 1.4$ & $52.9 \pm 4.7^{\&}$ \\
\hline LV fraction shortening (\%) & $21.51 \pm 0.23$ & $29.86 \pm 0.23^{*}$ & $18.05 \pm 0,70$ & $26.14 \pm 2.97^{\&}$ \\
\hline \multicolumn{5}{|l|}{ Interventricular septal } \\
\hline Dimension (diastole, mm) & $0.56 \pm 0.02$ & $0.54 \pm 0.03$ & $0.57 \pm 0.05$ & $0.58 \pm 0.01$ \\
\hline $\operatorname{LVd}(\mu \mathrm{L})$ & $3.71 \pm 0.03$ & $3.54 \pm 0.04$ & $3.72 \pm 0.1$ & $3.25 \pm 0.12^{\&}$ \\
\hline LV posterior wall (systole, mm) & $0.64 \pm 0.09$ & $1.05 \pm 0.07^{*}$ & $0.80 \pm 0.02$ & $0.75 \pm 0.12$ \\
\hline LV systolic volume $(\mu \mathrm{L})$ & $32.65 \pm 0.65$ & $22.13 \pm 0.87^{\#}$ & $31.43 \pm 3.44$ & $17.76 \pm 1.36^{\# \#}$ \\
\hline Stroke volume $(\mu \mathrm{l})$ & $25.42 \pm 1.01$ & $30.56 \pm 0.79$ & $22.88 \pm 1.22$ & $20.67 \pm 2.41$ \\
\hline Heart rate (bpm) & $501.2 \pm 31$ & $426.1 \pm 13$ & $470.7 \pm 11$ & $434.6 \pm 11.6$ \\
\hline
\end{tabular}

Echocardiographic measurements of cardiac parameters in mice following succinate intravenous injection for 5 days.

${ }^{*}<0.05$ versus control.

${ }^{*} \mathrm{p}<0.05$ versus GPR91 ${ }^{-1-}$

$\# p<0.01$ versus control.

$\# \mathrm{p}<0.01$ versus $\mathrm{GPR} 91^{-1-}$

wild mice treated with succinate, $\mathrm{p}<0.05$ ) was observed only in wild type mice, indicating that GPR91 is essential for succinate-induced hypertrophic effects on the heart. We also evaluated the expression levels of the aforementioned hypertrophic markers in cardiomyocytes isolated from GPR91 deficient animals. We found that in the absence of GPR91, injection of succinate was unable to induce the expression of ANP (a.u. $=100 \%$ in cells from WT mice vs $230 \pm 15 \%$ in cells from succinate treated WT mice $v s 15 \pm 2 \%$ in cells from GPR $91^{-/-}$mice treated with succinate vs $120 \%$ in cells from GPR91 $1^{-/-}, \mathrm{p}<0.001$ ), BNP (a.u. $=100 \%$ in cells from WT mice $v s 230 \pm 15 \%$ in cells from succinate treated WT mice vs $23 \pm 1 \%$ in cells from $\mathrm{GPR}^{-/-}$mice treated with succinate $v s 116 \pm 2 \%$ in cells from GPR91 ${ }^{-/}, \mathrm{p}<0.001$ ), and MYH7 (a.u. $=100 \%$ in cells from WT mice $v s 230 \pm 15 \%$ in cells from succinate treated WT mice vs $12 \pm 1.4 \%$ in cells from GPR91 ${ }^{-1-}$ mice treated with succinate, vs $108 \pm 4 \%$ in cells from $\mathrm{GPR}^{-/-}, \mathrm{p}<0.001$ ), (Figure 3A-C). The involvement of other key TCA cycle intermediate was not considered here since it was already demonstrated that succinate is the only agonist for GPR91 [21]. Taken together, these results show that high circulating levels of succinate lead to cardiac hypertrophy, through direct activation of GPR91. Nonetheless, the results also suggest that succinate-induced remodeling is not limited to its direct effects on the GPR91 in cardiac tissue, but might as well have its origin point in other organs besides the heart.

\section{Succinate-induced cardiomyocyte hypertrophy involves activation of MEK/ERK $1 / 2$ and HDAC5 pathways}

GPR91 can be coupled with different second messenger signaling systems, depending on the individual cell type where it is expressed. For instance, succinate uses both
$\mathrm{G}_{\mathrm{i}} / \mathrm{G}_{\mathrm{o}}$ and $\mathrm{Gq} / 11$ pathways to increase ERK1/2 phosphorylation and intracellular $\mathrm{Ca}^{2+}[21-23,31]$, which are, in fact, pathways involved in cardiac hypertrophy induced by G-protein coupled receptors [5,13,32,33]. In order to gain further insight into the mechanisms by which succinate induces cardiomyocyte hypertrophy and the dependence of this process on GPR91, we used primary cultures of

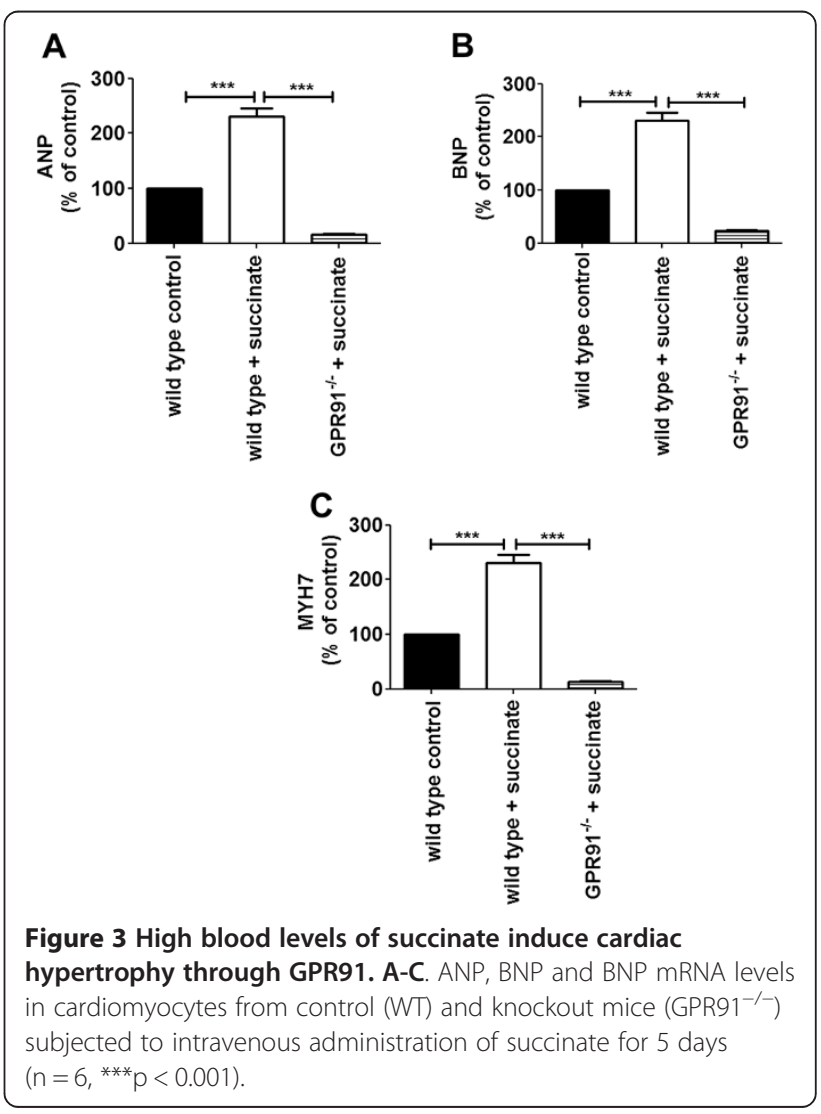


neonatal rat cardiomyocytes. We first investigated whether in vitro succinate treatment could also induce hypertrophy. For that, we tested several different concentrations of succinate, and measured cellular width after treatment with each of these concentrations $\left(500 \pm 12 \mu^{2}\right.$ for control cells; $682 \pm 20 \mu \mathrm{m}^{2}$ for cells treated with $25 \mathrm{mM}$ succinate; $800 \pm 15 \mu \mathrm{m}^{2}$ for $0.5 \mathrm{mM}$ succinate, $1000 \pm 15 \mu \mathrm{m}^{2}$ for $0.75 \mathrm{mM}$ succinate, $1041 \pm 25 \mu^{2}$ for $1 \mathrm{mM}$ succinate, $1083 \pm 13 \mu \mathrm{m}^{2}$ for $1.5 \mathrm{mM}$ succinate, $1080 \pm 10 \mu \mathrm{m}^{2}$ for $2 \mathrm{mM}$ succinate, $1085 \pm 20 \mu^{2}$ for $2.5 \mathrm{mM}$ succinate, Additional file 2: Figure S2). We found that neonatal cardiomyocytes exposed to $1 \mathrm{mmol} / \mathrm{L}$ succinate for 36 hours had increased cell surface area when compared to controls $\left(600 \mu \mathrm{m}^{2} \pm 15\right.$ in cells from control vs $1100 \mu \mathrm{m}^{2} \pm 20$ in cells from succinate treated cardiomyocytes, $\mathrm{p}<0.01, \mathrm{n}=60$ cells), (Figure 4A-B). In addition, succinate treatment led to an increase in ANP expression levels (a.u. $=0.93 \pm 0.06$ in cells from control vs $1.3 \pm 0.10$ in cells from succinate treated cardiomyocytes, $\mathrm{n}=3$ independent experiments, $\mathrm{p}<0.01$ ), (Figure 4C-D), providing evidence for onset cardiomyocyte hypertrophy, an effect that was not observed upon knockdown of succinate receptor with GPR91 siRNA. Real time PCR analysis indicated that siRNA against GPR91 abolished the expression of succinate receptor (Figure 5A) and prevented the increase of hypertrophic markers induced by succinate: ANP (a.u. = 100\% in control cells vs $180 \pm 8 \%$ in succinate treated cells $v s$ $100 \pm 1.4 \%$ in cells with GPR91siRNA, $\mathrm{p}<0.001$ ) and BNP (a.u. $=100 \%$ in control cells vs $180 \pm 8 \%$ in succinate treated cells vs $95 \pm 1.4 \%$ in cells with GPR91siRNA, $\mathrm{n}=3$

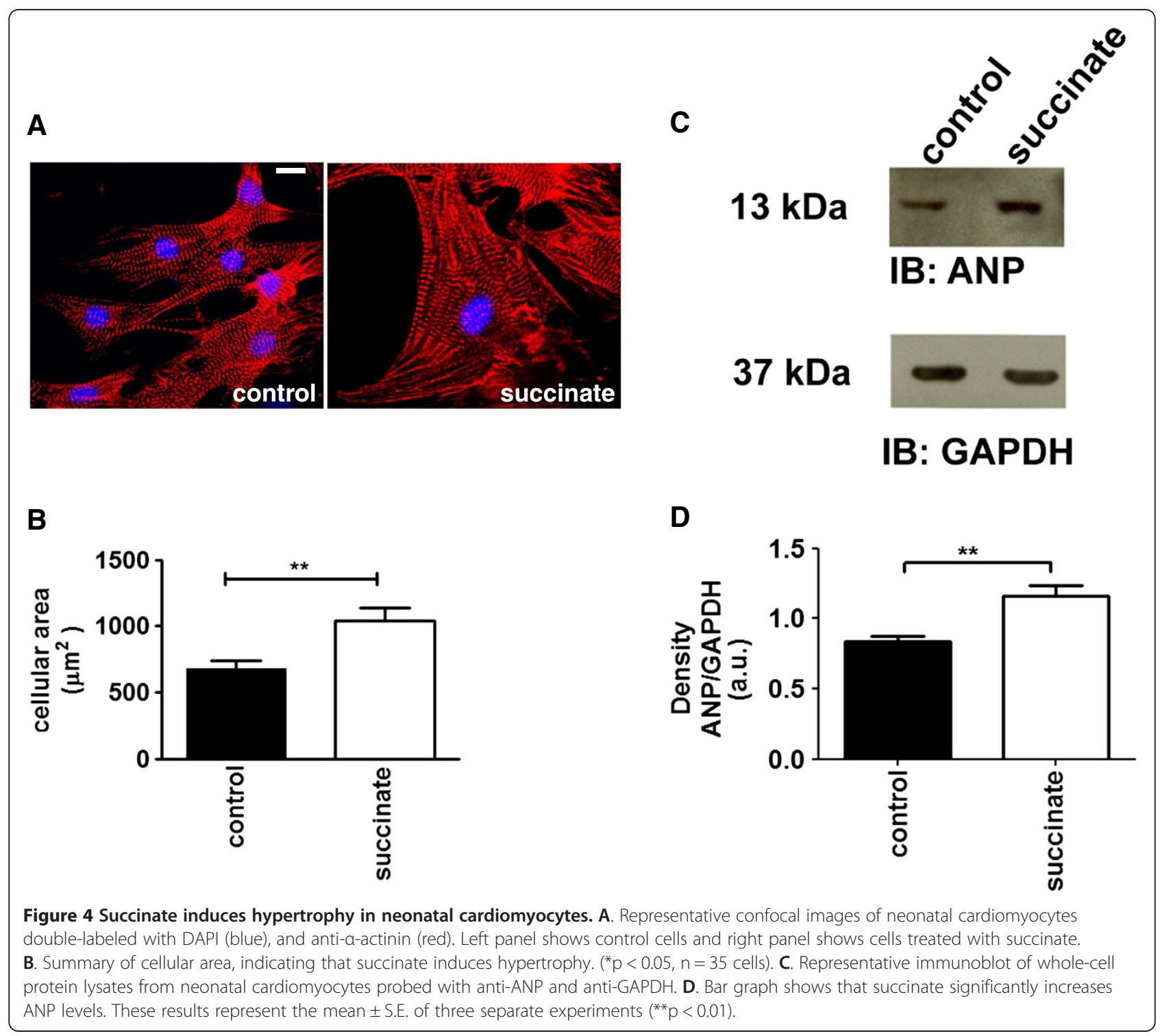




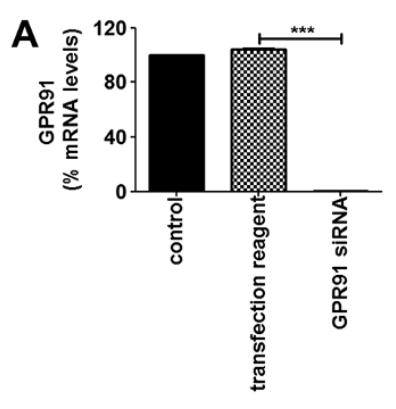

B

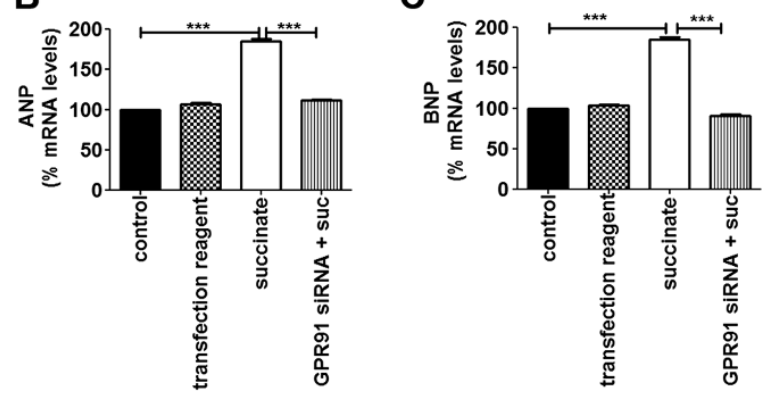

Figure $\mathbf{5}$ Hypertrophic effect of succinate in cardiomyocytes requires GPR91 expression. A. Real time PCR showed significant knockdown of GPR91 mRNA levels in cells transfected with siRNA against GPR91 ( $n=3$ independent experiments, $\left.{ }^{* *} p<0.001\right)$. B-C. Knockdown of GPR91 decreased ANP and BNP mRNA levels. $\left.{ }^{* * *} p<0.001\right)$.

independent experiments, $\mathrm{p}<0.001$ ), (Figure $5 \mathrm{~B}-\mathrm{C}$ ). These findings show that succinate causes hypertrophy due to a direct activation of GPR91 in cardiomyocytes.

Because ERK1/2 phosphorylation is a classical MAPK pathway activated in cardiomyocyte hypertrophy [13,32], and GPR91 activation is known to be associated with the ERK1/2 signaling cascade [21,23,31], we investigated whether succinate treatment alters ERK1/2 phosphorylation levels in cardiomyocytes as well. We found that exposing cardiomyocytes to succinate increased phosphorylation of ERK1/2, without affecting its expression levels (a.u. $=0.58$ \pm 0.02 in control cardiomyocytes $v s 0.78 \pm 0.02$ in succinate treated cardiomyocytes, $\mathrm{p}<0.01, \mathrm{n}=3$ independent experiments). We also observed that efficient silencing of GPR91 prevented the increase in ERK1/2 phosphorylation upon succinate treatment (a.u. $=0.58 \pm 0.02$ in control cardiomyocytes $v s 0.89 \pm 0.05$ in succinate treated cardiomyocytes vs $0.70 \pm 0.03$ in succinate treated cardiomyocytes transfected with GPR91siRNA, $\mathrm{p}<0.01, \mathrm{n}=3$ independent experiments), (Figure 6A-B). Moreover, the effects of succinate on cellular area and ANP expression were prevented by PD098059, an inhibitor of MEK1/2, (a.u. $=100 \%$ in control cells $v s 180 \pm 12 \%$ in cells treated with succinate $v s$ $125 \pm 5 \%$ in cells treated with succinate in the presence of PD098059, vs $109 \pm 4 \%$ in PD098059 treated cells alone; (fluorescence intensity: a.u. $=62500 \pm 500$ in control cells vs $87500 \pm 763$ in cells treated with succinate vs $50500 \pm$ 10000 in cells treated with succinate in the presence of PD098059, vs $71000 \pm 577 \%$ in PD098059 treated cells alone; $n=45, p<0.01$ ), (Figure $6 C-E$ ). We observed a very low expression of ANP, close to the control level. Since PD098059 is specific to MAPK inhibition, this data may suggest the existence of another protein, downstream to the MAPK inhibition, that negatively feedbacks the pathway, inactivating other important intermediate or adding to MEK inhibition, contributing to the lower activity caused by PD098059 [34-36]. However, altogether these findings show that MEK/ERK cascade is a crucial downstream pathway of the hypertrophic effects induced by succinate.

Additional important signaling cascades that are wellknown to be involved in cardiomyocyte hypertrophy are the calcineurin-NFAT $[2,3]$ and the histone deacetylase (HDAC) [37] pathways, both activated upon an increase in intracellular $\mathrm{Ca}^{2+}$ signals [38]. We have previously demonstrated that succinate increases intracellular $\mathrm{Ca}^{2+}$ transients in cardiomyocytes [22]. Thus, we now investigated whether exposing cardiomyocytes to succinate would trigger the above-mentioned $\mathrm{Ca}^{2+}$-dependent hypertrophic signaling cascades. We found that succinate did not activate NFAT, represented by the absence of NFAT in the nucleus upon succinate treatment (Additional file 3: Figure S3A-B). Instead, succinate activated calmodulin kinase II $\delta$ (CaMII)), (a.u. $=1.75 \pm 0.06$ in control cells, vs $2.30 \pm 0.1$ in succinate treated cells, $\mathrm{n}=3, \mathrm{p}<0.01$ ), (Figure 7A-B), and HDAC5 signaling pathway (Figure 7C-E). HDAC5 translocated from the nucleus to the cytosol upon succinate treatment, an effect that was prevented by KN93, an inhibitor of CaMKIII [39], (a.u. $=93000 \pm 1528 \%$ in control cells, $v s 46000 \pm 3000 \%$ in succinate treated cells, $v s$ $82000 \pm 9000 \%$ in succinate and KN93 treated cells, vs $93000 \pm 2000 \%$ in KN93 treated cells alone, $\mathrm{p}<0.001$, $\mathrm{p}<0.01$ ), (Figure $7 \mathrm{C}-\mathrm{D}$ ). The increase in cellular area induced by succinate was also prevented by KN93 treatment (a.u. $=100 \pm 3.68 \%$ in control cells, vs $180 \pm 5.45 \%$ in succinate treated cells, vs $117 \pm 8.35 \%$ in succinate and KN93 treated cells, vs $114 \pm 0.8 \%$ in KN93 treated cells alone, $\mathrm{p}<0.001, \mathrm{p}<0.01$ ), (Figure 7E). Part of KN93 effect on cellular area might be due to its unspecific effect as an antagonist. Validating this signaling pathway we further found that efficient silencing of GPR91 prevented both the translocation of HDAC5 from the nucleus to the cytosol (a.u. $=91667 \pm 4410$ in control cells, vs $88333 \pm 4410$ in GPR91 siRNA cells, vs $50667 \pm 3480$ in succinate treated cells, vs $89667 \pm 333.3$ in GPR91 siRNA and succinate treated cells, $\mathrm{p}<0.001$ ), and the increase in cellular area induced by succinate (a.u. $=102$ $\pm 0.57 \%$ in control cells, vs $84 \pm 0.57 \%$ in GPR91 siRNA cells, vs $156 \pm 2 \%$ in succinate treated cells, vs $103.3 \pm 8.8 \%$ in GPR91 siRNA and succinate treated cells, $\mathrm{p}<0.001$ ), (Additional file 4: Figure S4A-C). These results indicate that 
A

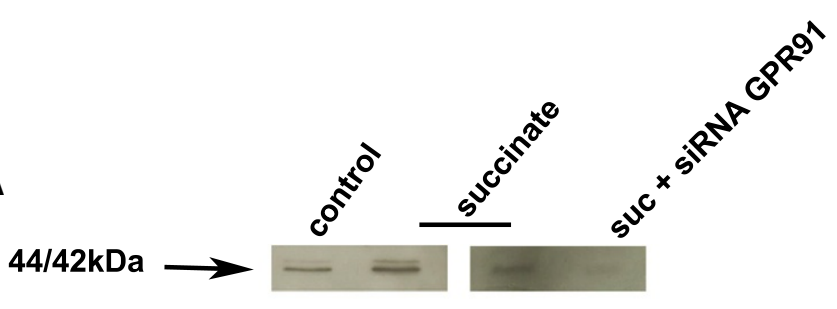

IB: $p$-ERK1/2

$40 \mathrm{kDa}$

IB: ERK1/2

B

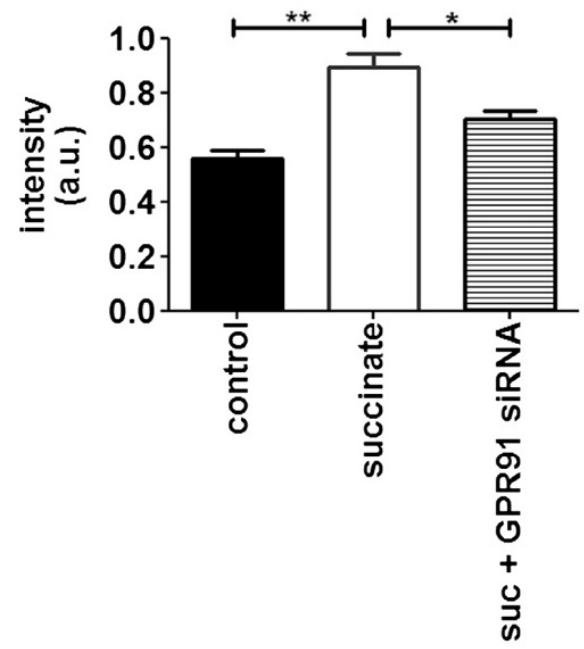

C

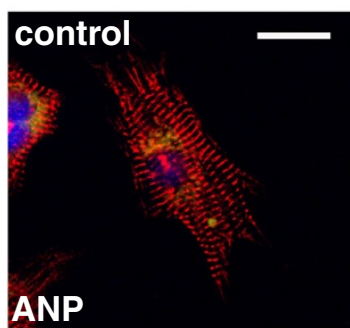

D

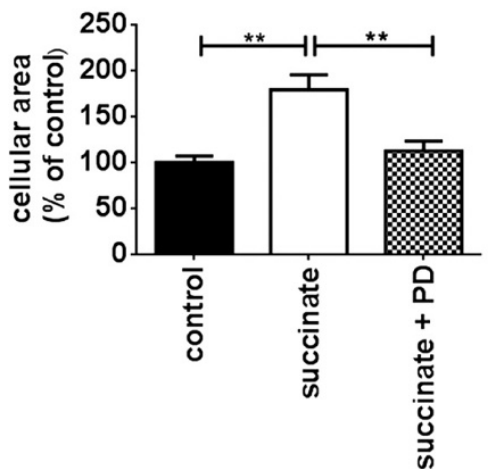

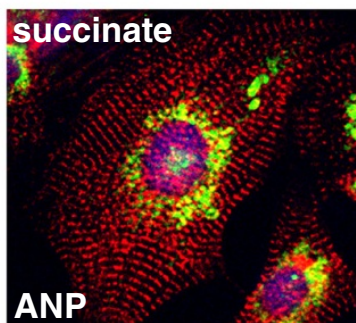

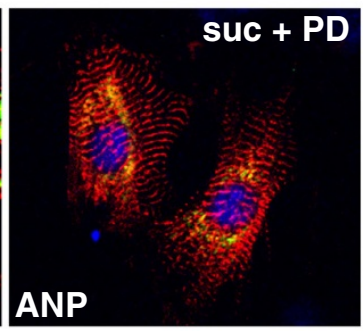

E

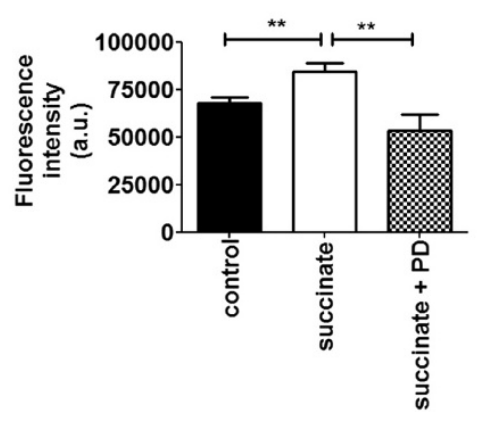


(See figure on previous page.)

Figure 6 Succinate activates the ERK1/2 hypertrophic signaling pathway. A. Immunoblot of whole cell lysates showing increased phosphorylation of ERK1/2 and absence of phosphorylated ERK1/2 when GPR91 is silenced with siRNA. B. Bar graph shows that succinate significantly increases phosphorylation of ERK1/2 levels and fails to increase ERK1/2 phosphorylation when GPR91 is efficiently silenced. These results represent the mean \pm S.E. of three separate experiments $(* * 0<0.01)$. C. Cells were treated with succinate and ERK1/2 inhibitor PD 098059 . Immunofluorescence staining with DAPI (blue), anti-a-actinin (red) and ANP (green). D-E. Summary of cellular area and fluorescence intensity indicating that inhibition of ERK1/2 signaling pathway reverses the hypertrophic effect of succinate. ${ }^{* *} p<0.01, n=50$ cells).

succinate causes cardiomyocyte hypertrophy through the activation of CaMKII//HDAC5 pathway.

To verify whether succinate triggers similar hypertrophic signaling cascades in vivo as well, we intravenously administered $0.066 \mathrm{mg} / \mathrm{kg}$ succinate in 8-week-old rats. Succinate was injected for 5 days, once a day, and the expression pattern of phospho-ERK $1 / 2$ and changes in intracellular $\mathrm{Ca}^{2+}$ transients were evaluated in freshly isolated adult cardiomyocytes. We found that high circulating levels of succinate increased the expression of phosphoERK1/2 compared to control cells (a.u. $=1 \pm 0.3$ in cells from control rats vs $2 \pm 0.25$ in cells from succinate treated cardiomyocytes, $\mathrm{p}<0.01, \mathrm{n}=3$ ), (Additional file 5 : Figure S5A-B). We also found that administration of succinate for 5 consecutive days modulated $\mathrm{Ca}^{2+}$ transients in isolated ventricular myocytes loaded with the $\mathrm{Ca}^{2+}$ fluorescent probe fluo-4/AM. As expected, succinate increased the amplitude $\left(3.8 \pm 0.4 \mathrm{~F} / \mathrm{F}_{0}\right.$ in cells from control rats vs $5.2 \pm 0.6 \mathrm{~F} / \mathrm{F}_{0}$ in cells from succinate treated cardiomyocytes, $\mathrm{p}<0.01, \mathrm{n}=40$ cells), and decreased the decay rate of the $\mathrm{Ca}^{2+}$ transient, $(950 \pm 9 \mathrm{~ms}$ in cells from control rats vs $920 \pm 7 \mathrm{~ms}$ in cells from succinate treated cardiomyocytes, $\mathrm{p}<0.05, \mathrm{n}=40$ ), (Additional file 6: Figure S6A-D). Collectively, these results show that succinate activates intracellular hypertrophic signaling cascades, both in vitro and in vivo.

Ischemic diseases increase succinate blood level in patients Ischemia is known to raise plasma succinate to millimolar levels in rodents [40]. We now used HPLC to evaluate the concentration of circulating succinate in human serum. For that, we first used serum samples of rodents previously subjected to ischemia-reperfusion procedure, to standardize the method $(\mathrm{p}<0.001$, Additional file 7 : Figure S7). We then investigated whether patients with hypertrophic cardiomyopathy associated with ischemia had altered levels of succinate in their blood flow. Nine patients diagnosed with acute myocardial infarction and/or chronic coronary artery disease showed high blood concentration of succinate, $(0.9 \pm 0.1 \mathrm{mmol} / \mathrm{L}$ of succinate in serum of patients with coronary artery disease $v s 1 \pm 0.2 \mathrm{mmol} / \mathrm{L}$ of succinate in patients with acute myocardial infarction $v s$ $2.69 \mathrm{mmol} / \mathrm{L}$ of succinate in patients with myocardial infarction plus coronary artery disease), compared with 6 control subjects of similar age, with undetectable serum levels of succinate (Table 3). Moreover, we found elevated levels of NT-pro-BNP in all subjects with ischemic disease, although higher levels of NT-pro-BNP were detected in patients with chronic coronary artery disease in comparison with patients with acute myocardial infarction, (coronary artery disease: $8101 \pm 4524 \mathrm{pg} / \mathrm{mL}$ vs $171 \pm$ $101 \mathrm{pg} / \mathrm{mL}$ acute myocardial infarction). To verify whether other more severe acute ischemic conditions could also cause changes in succinate blood levels, we measured succinate concentration in the serum of patients that underwent hepatic transplantation. In these patients, we evaluated the concentration of succinate 1 hour and 6 hours post transplantation (Table 4). We found that ischemia-reperfusion injury elevated succinate levels in a time dependent manner $(1.90 \pm 0.2 \mathrm{mmol} / \mathrm{L}$ of succinate 1 hours post transplantation and $2.36 \pm 0.2 \mathrm{mmol} / \mathrm{L}$ of succinate 6 hours post transplantation). More information about the patients can be seen elsewhere (Additional file 8: Table S1). Although preliminary, these data suggest that succinic acid accumulation in the blood is a possible marker to indicate the presence of ischemia and a potential target to prevent further damage, such as cardiomyocyte hypertrophy.

\section{Discussion}

Cardiomyocyte hypertrophy is among the most common causes of ischemic heart disease and may result in myocardial infarction, thus promoting further ischemia. Even though this complex syndrome has been extensively investigated, there are still many aspects that remain elusive. In this work, using both human and rodent systems, we propose that succinate plays a key role in pathological cardiomyocyte hypertrophy. Moreover, our results shed some light on the mechanisms by which succinate, through its specific receptor GPR91 activation, induces hypertrophic cardiomyopathy.

Hypertrophic stimuli are mediated by several intracellular signaling cascades that ultimately cause reactivation of fetal cardiac genes involved in hypertrophy [41,42]. A central signaling cascade that has been implicated in the development of cardiac hypertrophy is the mitogen activated protein kinase (MAPK) cascade consisting of the kinases rapid activation of fibrosarcoma (Raf), MAP/ERK kinase (MEK1/2), and ERK1/2 [43]. HDAC is another well-established effector in the transmission of cardiac stress to hypertrophic gene expression. Here we show that activation of GPR91 by succinate causes phosphorylation of ERK1/2, as already 


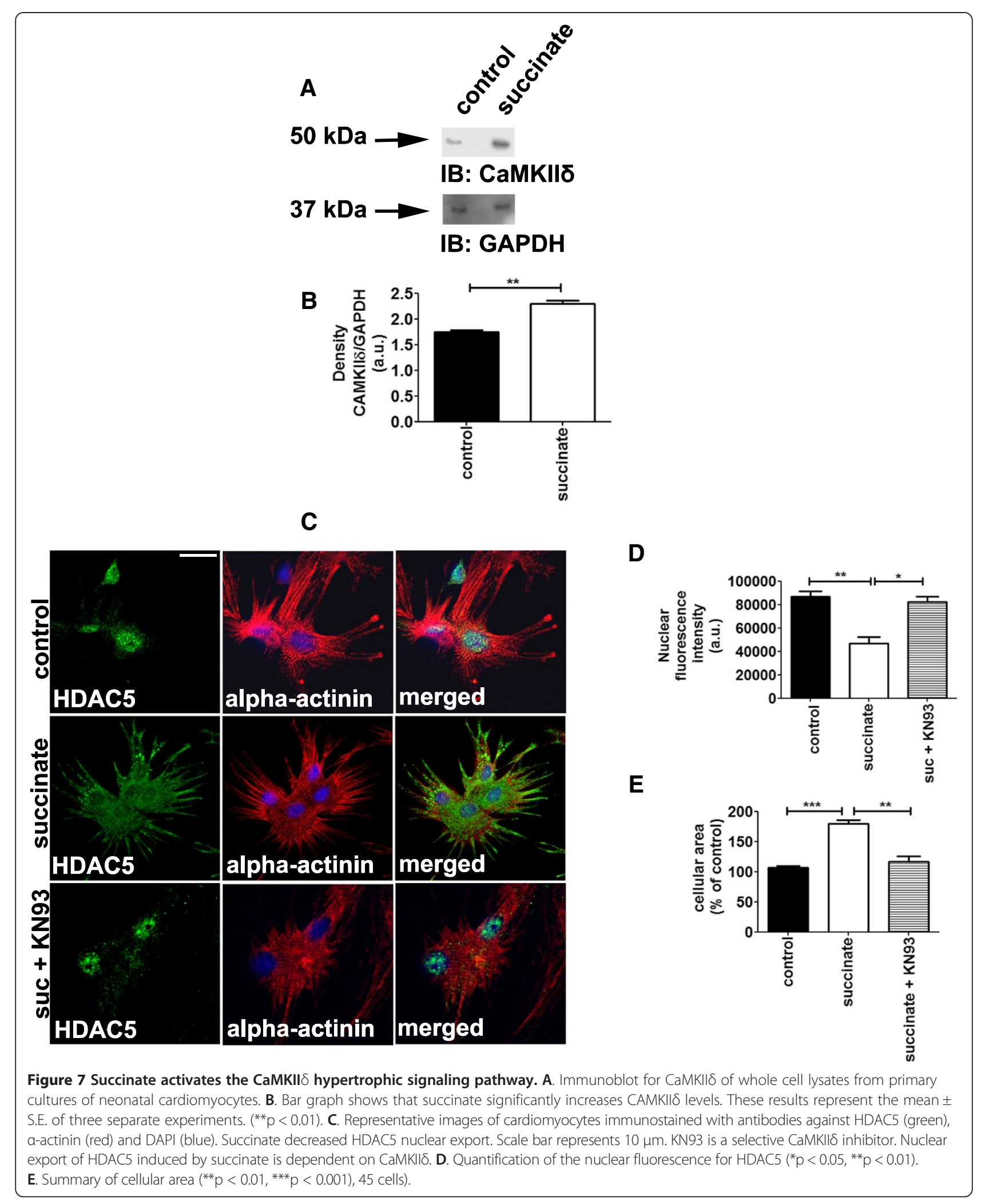


Table 3 Characteristics of the control patients and cardiac and plasma levels of succinate

\begin{tabular}{ll}
\hline Study characteristics & \\
\hline Number patients, $\mathrm{n}$ & 15 \\
Control & 6 \\
Cardiac & 9 \\
Median age, years & $62 \pm 2.7^{*}$ \\
Pathological condition & $\begin{array}{l}\text { Number of } \\
\text { patients }\end{array}$ \\
Coronary artery disease, $\mathrm{n}$ & 5 \\
Acute myocardial infarction, $\mathrm{n}$ & 3 \\
Coronary artery disease + Acute myocardial & 1 \\
infarction, $\mathrm{n}$ & \\
Total & 9 \\
Median blood levels NT-pro-BNP (pg/mL) & \\
Coronary artery disease & $8101 \pm 4524^{*}$ \\
Acute myocardial infarction & $171 \pm 101^{*}$ \\
Coronary artery disease + Acute myocardial & 25000 \\
infarction & \\
Median blood levels succinate (mmol/L) & \\
Coronary artery disease & $0.9 \pm 0.1^{*}$ \\
Acute myocardial infarction & $1 \pm 0.2^{*}$ \\
Coronary artery disease + Acute myocardial & 2.69 \\
infarction & \\
\hline
\end{tabular}

*The results are expressed as mean \pm S.E.M.

demonstrated in other cell types [21,23,44]. Additionally, we found that succinate increased intracellular $\mathrm{Ca}^{2+}$ transients required for activation of CaMKII $\delta$ and consequent HDAC5 phosphorylation. The current findings confirm previous data [21-23,31] and extend them by now showing for the first time that succinate in vivo also promotes

Table 4 Patients characteristics and serum levels of succinate post- hepatic transplantation

\begin{tabular}{ll}
\hline Study characteristics & \\
\hline Number patients, $\mathrm{n}$ & 8 \\
Median age, years & $46 \pm 7^{*}$ \\
Pathological condition & $\begin{array}{l}\text { Number of } \\
\text { patients }\end{array}$ \\
Cirrhosis due to hepatitis C & 4 \\
Cirrhosis due to Wilson disease & 2 \\
Cirrhosis due to alchohol and hepatocellular & 1 \\
carcinoma & \\
Cirrhosis due hepatitis C and hepatocellular & 1 \\
carcinoma & \\
Total & 8 \\
Median blood levels succinate (mmol/L) & Median (mmol/L) \\
1 hour post transplantation & $1.90 \pm 0.2^{*}$ \\
6 hours post transplantation & $2.36 \pm 0.3^{*}$ \\
\hline
\end{tabular}

*The results are expressed as mean \pm S.E.M. increases in intracellular $\mathrm{Ca}^{2+}$ transient in ventricular myocytes. Moreover, our results are in agreement with previous reports that indicate CaMKII $\delta$ as the main pathway involved in pathological hypertrophy $[45,46]$. Although ERK1/2 pathway is also known to induce cardiac hypertrophy, in part by activating a crosstalk with the calcineurinNFAT circuit [47], we found that under our experimental conditions, succinate did not induce translocation of NFAT to the nucleus to activate pro-phypertrophic gene expression. It is known that calcineurin-NFAT signaling is controlled by other kinases that can directly phosphorylate the $\mathrm{N}$-terminal regulatory domain of NFAT, antagonizing its nuclear occupancy [48-50]. Therefore, we cannot rule out that succinate could activate such kinases in cardiomyocytes, including JNK, GSK3, and p38. Indeed, activation of p38 pathway by succinate has been demonstrated in other cell types [30]. In cardiomyocytes, recent study demonstrated that succinate could activate PI3K/Akt signaling cascade [51], which is another pathway also implicated in cardiac hypertrophy [52].

Intravenous administration of succinate increases plasma renin activity and causes a dose-dependent increase in blood pressure, that could be blocked by angiotensin-converting enzyme inhibitors [21,23]. Moreover, high circulating succinate concentration was detected in spontaneously hypertensive rats [40]. Under our experimental conditions, we found that the mean arterial blood pressure was high after 4 consecutive days of succinate treatment, and shifted back to normal values at the final day of the experiment. We have not investigated the reason for such an oscillatory pattern of blood pressure, but it is possible that the succinate-treated animals experienced a type of compensatory response due to the abnormal succinate exposure. Indeed, blood pressure adaptation to hormone stimulation is a natural process, and has been broadly described [53]. Corroborating previous data, we also found that succinate effects on cardiac functions were partially reverted by an angiotensin-II receptor antagonist losartan. Losartan prevented the increase in stroke volume and cardiac output triggered by succinate, confirming that, at a systemic level, RAS activation plays a role in succinate-induced change in blood pressure. We also discovered that losartan partially prevented the expression of the hypertrophic fetal genes induced by succinate, indicating that, at least in part, the observed succinate-induced cardiac remodeling could be a consequence of changes in blood pressure due to RAS activation. Despite the fact, that we have shown a significant increase in cardiomyocyte diameter by morphometric studies, we found no alteration in LVP wall thickness by echocardiography studies and no fibrosis in cardiac specimens. Considering these findings, we believe that we are observing early stages of cardiac hypertrophy in 5-day succinate treated rats, and we speculate that longer exposure to succinate will be necessary in order to observe substantial pathological indicators of 
cardiac hypertrophy. On the other hand, similar 5-day succinate injection protocol caused significant increase in cardiac hypertrophy in mice. These differences in the susceptibility to cardiac hypertrophy, by $i v$ administration of succinate, could be due to specie-sensitivity. If directly accessing the effect of succinate in primary culture of cardiomyocytes, a pathological type of hypertrophy is clearly demonstrated, by CaMKII $\delta$ activation, as well as by $\alpha$-SKA gene reexpression. Nevertheless, both with in vivo and in vitro studies, our data support a direct role of GPR91 in succinate-induced cardiac hypertrophy, since GPR91 ablation prevented: succinate-induced cardiac hypertrophy in GPR91KO mice, expression of hypertrophic markers, ERK1/2 activation, and intracellular HDAC5 translocation. Even though succinate can induce cardiac hypertrophy - through systemic augmentation of renin-angiotensin II activity and local activation of the above mentioned hypertrophic cellular signaling cascades in cardiomyocytes - GPR91 is a converting point in both of them. We still cannot rule out the possibility that succinate might bind to other not yet characterized receptor(s), which may activate distinct intracellular signaling pathway to differently regulate cell function.

Myocardial ischemia is accompanied by a variety of metabolic alterations in myocardial tissue. Succinic acid, for instance, was observed to accumulate in severely as well as in moderately ischemic rabbit hearts, with a good correlation between degree plus duration of myocardial ischemia and tissue succinate content [54]. Using HPLC measurements, we now show that upon ischemic injury, succinate concentration also reaches blood flow. We found that succinate concentration increases in the serum of patients with cardiac hypertrophy associated with acute or chronic obstructive coronary artery diseases. Whether succinate was among the causes of the cardiac hypertrophy observed in these patients, or a consequence of the ischemic process, or both, still remain to be determined. However, our data show that succinate induces cardiomyocyte hypertrophy in cardiac cells though direct GPR91 activation. Thus, the presence of high circulating levels of succinate in the blood flow might reinforce the already installed hypertrophic phenotype that can lead to myocardial infarction, one of the ultimate consequences of ischemic heart disease.

High succinate concentrations have been detected in several other scenarios such as in blood samples from rodent models of hypertension and metabolic disease (type 2 diabetes) [40,55], in clinical specimens of patients with peritonitis [55], as well as in perfusate of rat liver under hepatic ischemia [15]. In line with these reports, we found that succinate is also increased in serum of patients that underwent liver transplant, a process that involves a transitory ischemic condition. Indeed cardiovascular diseases make up the most common cause of death in patients with functioning allografts at all times after transplantation, accounting for $30 \%$ mortality overall, with highest rates in the peritransplantation period. Therefore, GPR91 antagonism in preservation solution for transplantation could represent, for instance, a real benefit to help preventing cardiac hypertrophy due to organ transplant. Moreover, during transplant, succinate has been pointed as an 'alarming' signal able to trigger GPR91 to sense immunological danger and to increase allograft rejection [56]. In fact, a multiorgan failure has been reported in a liver-intestine transplant from a pediatric donor with a succinate- cytochrome C-reductase deficiency, a condition that raises succinate blood levels [57]. It has also been demonstrated that a patient with succinate dehydrogenase deficiency, another condition that also leads to extracellular accumulation of succinate, exhibited congestive heart failure [58]. Thus, succinate might be a clinical marker for ischemia, and its increase at blood level during organ transplant should be prevented, since it may cause, among other damages, cardiac hypertrophy.

\section{Conclusions}

Collectively, our data strengthen previous results showing that succinate can be found outside the cell during ischemia and act as a circulating hormone. Our results also expand previous findings by showing that succinate, through GPR91 activation, induces cardiac hypertrophy. Interfering with this mechanism might prove as a powerful strategy in the prevention of cardiac hypertrophy and consequently heart failure.

\section{Methods}

\section{Materials and reagents}

Cardiomyocyte primary culture extracting kit was obtained from Worthington Biochemical Corporation (Lakewood, USA). Dulbeccos's Modified Eagle's Medium (DMEM), penicillin, streptomycin, amphotericin and fetal bovine serum (FBS) were purchased from Gibco (Grand Island, USA). Cytosine $\beta$-D-arabinofuranoside (ARA-C), fibronectin, $\mathrm{KN}-93\left(\mathrm{Ca}^{2+} /\right.$ calmodulin-dependent protein kinase II inhibitor) and ultra-pure succinic acid were obtained from Sigma (St. Louis, USA), Fluo-4/AM, DAPI and secondary antibodies conjugated to Alexa-488, Alexa-633 and Silencer kit were from Ambion, Life Technologies (New York, USA). Trizol reagent was obtained from Invitrogen (Eugene, USA). Polyclonal anti- GAPDH, anti- HDAC5, and anti-ANP antibodies were from Santa Cruz Biotechnology (Santa Cruz, USA). Monoclonal anti - Phospho-p44/42 MAPK and polyclonal anti-MEK1/2 were purchased from Cell Signaling Technology (Boston, USA), monoclonal antiCAMK2 $\delta$ from Abnova (Taipei, Taiwan). Hydromount was from National Diagnostics (St. Louis, USA). PD- 98059 (MEK 1/2 innhibitor) was from Calbiochem (Germany). Enhanced chemiluminescence (ECL-plus Western Blotting 
Detection System) and peroxidase-conjugated antibodies were purchased from Amersham Biosciences (Buckinghamshire, UK). All other reagents were of the highest quality commercially available.

\section{Human samples}

Use of blood samples from patients with acute coronary disease, acute myocardial infarction and hepatic transplant as well as the term of free and informed consent, n: 03182712.2.0000.5149 and n: 00907612.0.0000.5149, respectively, were approved by the Ethics Committee in Research of UFMG-COEP.

\section{Animals}

In this study, we used adult (250 g) and neonatal (3-5 days old) Wistar rats, acquired from Centro de Bioterismo (CEBIO) of the Federal University of Minas Gerais. GPR91 ${ }^{-/}$mice (C57BL/6 background) were provided by Novartis. Animals were maintained on a standard diet and housed under a 12-hour light-dark cycle. All animal experiments were performed in accordance to the Guide for the Care and Use of Laboratory Animals published by the US National Institutes of Health (NIH publication No. 85-23, revised 1996).

\section{Genotyping of mice}

Mice were characterized by PCR using genomic DNA extracted from tail biopsies. DNA was digested with the REDExtract-N-Amp Tissue PCR Kit (Sigma-Aldrich). Routine genotyping by PCR was performed using the following primers: The forward primer sequence was $5^{\prime}$ TTA CGC CAC TGG GAA CTG GA3' and the reverse primer sequence was 5' TTG ATG GCC TTC TGG GAA CA 3'[56]. Primers for GPR91 were designed using the software Primer3 based on the sequence deposited in the NCBI Nucleotide Bank NM_001001518.1.

\section{Adult cardiomyocyte isolation}

Adult ventricular myocytes were freshly isolated as previously described $[59,60]$ from adult Wistar rats previously treated with $0.066 \mathrm{mg} / \mathrm{kg}$ succinate intravenously. Cells were incubated in DMEM and the experiments were carried out at room temperature $\left(22-24^{\circ} \mathrm{C}\right)$.

\section{Primary culture of neonatal cardiomyocytes}

Cardiomyocytes were isolated from hearts of 3-5 days old Wistar rats according to the manufacturer's instructions (Worthington Biochemical Corporation). The rats were anesthetized with sodium pentobarbital $(50 \mathrm{mg} / \mathrm{kg}$ body weight intraperitoneally), and the beating hearts were removed surgically. Cells were resuspended in Dulbeccos's Modified Eagle's Medium (DMEM) supplemented with $10 \%$ fetal bovine serum (FBS), 100 units $/ \mathrm{ml}$ penicillin, $100 \mu \mathrm{g} / \mathrm{ml}$ streptomycin and $0.25 \mu \mathrm{g} / \mathrm{ml}$ anfotericin-b. Cardiomyocytes were plated into fibronectincoated culture dishes or flasks, and incubated at $37^{\circ} \mathrm{C}$ in a $5 \% \mathrm{CO}_{2}$ incubator. Two days after plating, cells were rinsed with DMEM and fed for another $24 \mathrm{~h}$ with regular culture medium, now including $20 \mu \mathrm{g} / \mathrm{ml}$ cytosine $\beta$-D-arabinofuranoside (ARA-C). The ARA-C was added to the culture medium for $48 \mathrm{~h}$ to inhibit growth of noncardiomyocyte cells. The medium was then replaced with FBS-free DMEM with or without succinate $(1 \mathrm{mmol} / \mathrm{L})$ for $12 \mathrm{~h}$ and subsequently changed to $10 \%$ FBS-containing medium with or without succinate $(1 \mathrm{mmol} / \mathrm{L})$ for $24 \mathrm{~h}$. Cardiomyocytes were used in experiments at the fourth day of culture. At this point, there were approximately 5-6 $\times 10^{4}$ cardiomyocytes per culture dish, which comprised approximately $95 \%$ the total cell population $[22,59,61]$. The cells were then used for immunofluorescence, western blot or qRT-PCR analysis.

\section{Preparation of siRNA}

Potential target sites within the GPR91 gene were selected and then searched with NCBI Blast to confirm specificity for the receptor. The siRNAs for GPR91, and a siRNA containing the same nucleotides for GPR91 but in a scrambled sequence were prepared by a transcriptionalbased method using the Silencer kit, according to the manufacturer's instructions. The sense and antisense oligonucleotides of siRNA were, respectively: $5^{\prime}$ AAT CTC TAA TGC CAG CCA ATT CCT GTC TC $3^{\prime}$ and 5' AAA ATT GGC TGG CAT TAG AGA CCT GTC TC 3 '. For siRNA studies, day 4 neonatal cardiomyocyte cultures were treated with $100 \mathrm{nM}$ of each siRNA [22]. We used single wall carbon nanotubes (CNT) to deliver siRNA and silence GPR91, as previously described [62]. Cardiomyocytes were incubated at $37^{\circ} \mathrm{C}$ in an atmosphere of $5 \% \mathrm{CO}_{2}$ for 48 hours prior to use.

\section{Western blotting}

Cardiomyocytes were harvested as described and protein content was quantified according to Bradford protein assay. For ANP, $50 \mu \mathrm{g}$ of whole cell proteins were separated by $12 \%$ SDS-PAGE. For GAPDH detection, mouse monoclonal anti-GAPDH antibody was used at a dilution of 1:1500. For ERK 1/2 detection, a rabbit polyclonal antibody was used at dilution of 1:500. For ANP detection rabbit polyclonal anti-ANP was used at a dilution of 1:200. For Phospho-p44/42 MAPK (ERK1/2) detection, a rabbit monoclonal antibody was used at a dilution of 1:1000. For CaMKII $\delta$ detection, a mouse monoclonal anti- antibody was used at a dilution of 1:500. The antibody incubation proceeded for $2 \mathrm{~h}$ at room temperature. After washing, blots were incubated in HRP-conjugated goat-anti-mouse or rabbit IgG1 secondary antibody at a dilution of 1:5000 at room temperature for $1 \mathrm{~h}$. Immunodetection was carried out using enhanced chemiluminescence [22,59]. 


\section{Immunofluorescence}

Confocal immunofluorescence was performed as described [22,59]. Briefly, cardiomyocytes were seeded onto 6 well culture dishes, treated with succinate $1 \mathrm{mM}$ and 36 hours later were fixed with $4 \%$ paraformaldehyde, permeabilized with PBS $1 \mathrm{X} /$ Triton $0.5 \%$ and non-specific binding was blocked (PBS, BSA 10\%, Triton 0.5\%, goat serum 5\%) for 1 hour. Cells were then incubated with anti-ANP (1:10), anti $\alpha$-actinin (1:150), anti-HDAC5 (1:50) or with antiNFAT (1:50) for 2 hours at room temperature. This was followed by incubation with specific secondary antibodies conjugated with Alexa-Fluo 488 or 633 (1:500) for 1 hour. Images were obtained using Zeiss LSM 510 confocal microscope (Thornwood, USA) [22,59].

\section{Measurement of intracellular $\mathrm{Ca}^{2+}$}

Intracellular $\mathrm{Ca}^{2+}$ was monitored in individual cardiomyocytes by line scanning and time lapse confocal microscopy as described previously $[22,59,60]$. Briefly, adult cardiomyocytes were incubated with Fluo-4/AM $(6 \mu \mathrm{mol} / \mathrm{L})$ for 30 minutes at $37^{\circ} \mathrm{C}$. Coverslips were transferred to a perfusion chamber on the stage of a Zeiss LSM510 confocal microscope. Cells were electrically stimulated at $1 \mathrm{~Hz}$ to produce steady-state conditions. Fluo-4 was excited at $488 \mathrm{~nm}$ and observed at 505-550 nm. Increases in $\mathrm{Ca}^{2+}$ were expressed as percent increase in Fluo-4 fluorescence over baseline $[22,63,64]$.

PD 98059 (MEK 1/2 inhibitor), KN93 (Ca ${ }^{2+} /$ calmodulindependent kinase II inhibitor) and losartan (AT1 angiotensin II receptor antagonist)

$10 \mu \mathrm{mol} / \mathrm{L}$ of PD or $1 \mu \mathrm{mol} / \mathrm{L}$ KN93 [39] was added combined of $1 \mathrm{mmol} / \mathrm{L}$ succinate to the cells. Losartan was administrated in the drinking water, once a day, for 5 days at doses of $200 \mathrm{mg} / \mathrm{l}$ [65].

\section{Intravenous administration of succinate and measurement of arterial blood pressure}

Animals were housed in a temperature-controlled room under a 12 hour light-dark cycle with water and standard rodent chow available ad libitum. Rats and mice under ketamine and xylazine anesthesia had the femoral vein catheterized for intravenous injection of succinate $(0.066 \mathrm{mg} / \mathrm{kg}$ in rats and $0.039 \mathrm{mg} / \mathrm{kg}$ in mouse) or PBS. Blood pressure was measured in unanesthetized animals by the tail-cuff method, MAP was recorded in rats for 5 days; at least 15 measurements were made daily with a BP-2000 blood pressure analysis tail-cuff System (isitech Systems). The mean systolic blood pressure and pulse rate were taken for each animal $[21,66]$.

\section{Real-time PCR}

Total RNA was isolated from adult and neonatal cardiomyocytes using TRIzol and cDNA synthesized using SuperScript
II kit (Invitrogen). DNA templates were amplified by real time PCR on the StepOnePlus ${ }^{\text {тM }}$ Real-Time PCR Systems (Applied Biosystems, CA) using the SYBR green method, as described. Sequence of the primers used are: ANP FW: 5'-GGATTTCAAGAACCTGCTAGA-3' and RE 5'-CTTCATCGGTC TGCTCGCTCA-3'; BNP5' AGACCACCGCTC TTGTGTGTG-3' and RE 5' CTGAC C CATACCTACCATGACACC-3'; MHC and GPR91 FW: 5'-TTACGCCACTGGGAACT GGA-3' and RE 5'-TTGA TGGCCTTCTGGGAACA-3 [22,61,67]: FW: 5' -CAG GCGGTGCTGTCTCTCTAT-3' and RE: 5'-GGCAGGGCATAACCCTCATA-3' for $\alpha$-SkA [61]. Experiments were performed in triplicate for each data point.

\section{Tissue preparation}

After administration for 5 days succinate the rats were weighed, anesthetized (i.p. sodium pentobarbital $80 \mathrm{mg} /$ BW plus ketamine chloridrate $10 \mathrm{mg} / \mathrm{BW}$ ) and perfused intracardially with Ringer's solution followed by $10 \%$ neutral buffer formalin (NBF). After fixation, the heart was removed, weighted and the relative organ weight was calculated per $100 \mathrm{~g}$ of body weight. Fragments of the heart were embedded in paraffin, sectioned $(5 \mu \mathrm{m})$ and mounted in silanized glass slides. For histological and morphometric studies, the sections were stained with hematoxylin and eosin or Masson's trichrome [68].

\section{Morphometry}

The quantitative analysis of myocyte cross-sectional height and nuclear diameter were measured in histological sections by using computer-assisted image analysis and the Scion Image software (http://www.scioncorp.com), as previously described [68]. For this purpose, digital images were obtained with a Nikon Coolpix 995 digital camera (Nikon Instruments Inc., Melville, USA).

\section{HPLC analysis}

Serum samples from humans were collected to determine succinate using HPLC as previously described [69]. Mice samples were collected under $\mathrm{CO}_{2}$ euthanasia, while human samples were collected from conscious individuals. All subjects had documented coronary atherosclerosis. Accurate details about the inclusion and exclusion criteria for this trial were previously published. All human subjects gave written informed consent, and the study was approved by the Institutional Review Committees at all sites.

\section{Echocardiography}

Animals were anaesthetized using a nose cone with isoflurane at $5 \%$ for one minute and the maintenance dose was $1.25 \%$. The anterior chest was shaved, and the animals were placed in supine position on an imaging stage equipped with built-in electrocardiographic electrodes for continuous heart rate monitoring and a proper heating pad to avoid 
hypothermia. In vivo cardiac function was assessed noninvasively using a high-frequency, high-resolution echocardiographic system consisting of a VEVO 2100 ultrasound

Machine equipped with a 30-40 MHz bifrequencial transducer (Visual Sonics, Toronto, Canada). High-resolution images were obtained as previously described [70-73].

\section{Statistical analysis}

Results are expressed as mean values \pm S.E., except where otherwise noted. Prism (GraphPad Software, San Diego, $\mathrm{CA}$ ) and Image J (NIH; Bethesda, MD) were used for data and image analysis, respectively. Statistical significance was tested using One-way ANOVA followed by Bonferroni test, and $\mathrm{p}$ value $<0.05$ was taken to indicate statistical significance.

\section{Additional files}

Additional file 1: Figure S1. Losartan partially reverted expression of ANP and MYH7 induced by succinate. A. ANP mRNA levels in freshly isolated adult cardiomyocytes from control, control with losartan, succinate treated and succinate treated in the presence of losartan rats. B. MYH7 mRNA levels in freshly isolated adult cardiomyocytes from control, control with losartan, succinate treated and succinate treated in the presence of losartan rats. (control $n=6$, control + losartan $n=3$, succinate $n=8$ and succinate + losartan $n=5,{ }^{* * *} p<0.001$ ).

Additional file 2: Figure S2. Succinate induces hypertrophy concentration dependent. A. Graph show different concentrations of succinate, and cellular width $\left(500 \pm 12 \mu \mathrm{m}^{2}\right.$ for control cells; $682 \pm 20 \mu \mathrm{m}^{2}$ for cells treated with $25 \mathrm{mM}$ succinate; $800 \pm 15 \mu \mathrm{m}^{2}$ for $0.5 \mathrm{mM}$ succinate, $1000 \pm 15 \mu \mathrm{m}^{2}$ for $0.75 \mathrm{mM}$ succinate, $1041 \pm 25 \mu^{2}$ for $1 \mathrm{mM}$

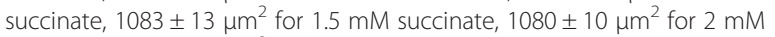
succinate, $1085 \pm 20 \mu^{2}$ for $2.5 \mathrm{mM}$ succinate).

Additional file 3: Figure S3. Succinate does not activate NFAT. Top: representative images of cardiomyocytes immunostained with antibodies against NFAT (green), a-actinin (red) and DAPI (blue). Scale bar represents $10 \mu \mathrm{m}$. Bottom: Quantification of NFAT nuclear fluorescence ( $p>0.05, n=45$ cells).

Additional file 4: Figure S4. Silencing of GPR91 prevented the translocation of HDAC5 and the increase in cellular area induced by succinate. A. Representative images of cardiomyocytes immunostained with antibodies against HDAC5 (red) and a-actinin (green). Silencing of GPR91 prevented the translocation of HDAC5 from the nucleus to the cytosol. Scale bar represents $10 \mu \mathrm{m}$. B. Quantification of the nuclear fluorescence for HDAC5 (*** $p<0.001), n=30$ cells). C. Quantification of the cellular area. $\left.{ }^{* *} p<0.01\right)$.

Additional file 5: Figure S5. Intravenous administration of succinate alters phosphorylation levels of ERK1/2. Top: representative immunoblot of whole-cell protein lysates from ventricular cardiomyocytes probed with anti-phospho ERK1/2 at Thr ${ }^{202 /} \mathrm{Tyr}^{204}$ site and anti-ERK/1/2. Bottom: Bar graph shows that succinate significantly increases ERK1/2 phosphorylation levels. These results represent the mean \pm S.E. of three separate experiments $\left({ }^{* *} \mathrm{p}<0.01\right)$.

Additional file 6: Figure S6. Intravenous administration of succinate alters global $\mathrm{Ca}^{2+}$ transients in adult ventricular cardiomyocytes. A - D. Global $\mathrm{Ca}^{2+}$ transients in freshly isolated adult rat cardiomyocytes. $\mathrm{Ca}_{i}^{2+}$ was monitored with Fluo-4/AM using confocal linescanning microscopy. Cells were examined after intravenous administration of succinate and compared to control. Images are pseudocolored according to the color scale shown at the right of panel A. Tracing under each panel shows the percent increase in fluorescence relative to baseline, and is representative of the indicated cell. E- F. Summary of succinate effects on $\mathrm{Ca}^{2+}$ transient amplitude. $\mathrm{Ca}^{2+}$ kinetics of decay (presented as T90) was significantly faster in cells after succinate treatment when compared to controls. $\left(* * * p<0.001,{ }^{*} p<0.05\right)$.

Additional file 7: Figure S7. Succinate increases in the serum of mice subjected to ischemia and reperfusion. A. The bar graph shows the mean concentration of succinate in the serum of control mice, sham and animals subjected to liver ischemia and reperfusion, $(n=3, p<0.001)$.

Additional file 8: Table S1. Additional health conditions and characteristics of the cardiac patients.

\section{Abbreviations}

ANP: Atrial natriuretic peptide; BNP: Brain natriuretic peptide; CaMK\|Iס: Calcium/calmodulin dependent protein kinase $\| \delta$; ERK 1/2: Extracellular signal-regulated kinase 1/2; GSK3: Glycogen synthase kinase 3; HDAC5: Histone deacetylase 5; JNK: c-Jun N-terminal kinase; MAP: Mean arterial pressure; MYH7: $\beta$ myosin heavy chain; NFAT: Nuclear factor of activated T-cells; NT-pro-BNP: N-terminal pro-B-type natriuretic peptide; phospho-ERK 1/2: Phosphorylated extracellular signal-regulated kinase 1/2; WT: Wild type.

\section{Competing interests}

The authors declare that they have no competing interests.

\section{Authors' contributions}

MFL, CJA and SG designed research; CJA, JARF, and MFL performed most research; PAS, AKS, ML, CRR, MBM, RR, performed selected experiment, JC, TMC, LOL, SG, RR, FAB, contributed new reagent or analytic tools; CJA analyzed data, CJA, JARF, and MFL wrote the paper.

\section{Acknowledgments}

We thank M. Jimena Amaya (Yale University, USA) for carefully reading the manuscript. The authors also acknowledge the technical assistance of Gilson Nogueira. This work was supported by grants from CAPES, FAPEMIG (Pronex), INCT- Carbon Nanotubes, CNPq, and HHMI.

\section{Author details}

'Department of Physiology and Biophysics, Federal University of Minas Gerais, Av. Antônio Carlos 6627, Belo Horizonte MG - CEP: 31270-901, Brazil. ${ }^{2}$ Department of Biochemistry and Immunology, Federal University of Minas Gerais, Av. Antônio Carlos 6627, Belo Horizonte MG - CEP: 31270-901, Brazil. ${ }^{3}$ Department of Physics, Federal University of Minas Gerais, Av. Antônio Carlos 6627, Belo Horizonte MG - CEP: 31270-901, Brazil. ${ }^{4}$ Department of Medicine, Federal University of Minas Gerais, Av. Antônio Carlos 6627, Belo Horizonte MG - CEP: 31270-901, Brazil. ${ }^{5}$ Novartis Institutes for Biomedical Research, Basel CH-4002, Switzerland. 'Department of Pharmacology, Ribeirão Preto, Medical School, University of São Paulo, São Paulo, Brazil. ${ }^{7}$ Department of Morphology, Federal University of Minas Gerais, Av. Antônio Carlos 6627, Belo Horizonte MG - CEP: 31270-901, Brazil.

Received: 14 June 2014 Accepted: 28 November 2014 Published online: 24 December 2014

\section{References}

1. Heineke J, Molkentin JD: Regulation of cardiac hypertrophy by intracellular signalling pathways. Nat Rev Mol Cell Biol 2006, 7:589-600

2. Wilkins BJ, Molkentin JD: Calcineurin and cardiac hypertrophy: where have we been? Where are we going? J Physiol 2002, 541:1-8.

3. van Rooij E, Doevendans PA, de Theije CC, Babiker FA, Molkentin JD, de Windt $\mathrm{L}$ : Requirement of nuclear factor of activated T-cells in calcineurin-mediated cardiomyocyte hypertrophy. J Biol Chem 2002, 277:48617-48626.

4. Berenji K, Drazner MH, Rothermel BA, Hill JA: Does load-induced ventricular hypertrophy progress to systolic heart failure? Am J Physiol Heart Circ Physiol 2005, 289:H8-H16.

5. Bers DM: Altered cardiac myocyte Ca regulation in heart failure. Physiology (Bethesda) 2006, 21:380-387.

6. Lentine KL, Brennan DC, Schnitzler MA: Incidence and predictors of myocardial infarction after kidney transplantation. J Am Soc Nephrol 2005, 16:496-506.

7. Munoz SJ, Elgenaidi H: Cardiovascular risk factors after liver transplantation. Liver Transpl 2005, 11:S52-S56. 
8. Raval Z, Harinstein ME, Skaro Al, Erdogan A, DeWolf AM, Shah SJ, Fix OK, Kay $\mathrm{N}$, Abecassis MI, Gheorghiade M, Flaherty JD: Cardiovascular risk assessment of the liver transplant candidate. J Am Coll Cardiol 2011, 58:223-231.

9. Lentine KL, Costa SP, Weir MR, Robb JF, Fleisher LA, Kasiske BL, Carithers RL, Ragosta M, Bolton K, Auerbach AD, Eagle KA: Cardiac disease evaluation and management among kidney and liver transplantation candidates: a scientific statement from the American Heart Association and the American College of Cardiology Foundation. J Am Coll Cardiol 2012, 60:434-480.

10. Mehta JL, Ding Z, Liu S, Wang X, Khaidakov M: Hypertension, TLR4 activation in brain and cardiac hypertrophy. Cardiovasc Res 2014, 103:3-4.

11. Molkentin JD, Dorn GW: Cytoplasmic signaling pathways that regulate cardiac hypertrophy. Annu Rev Physiol 2001, 63:391-426.

12. Molkentin JD: Dichotomy of $\mathrm{Ca} 2+$ in the heart: contraction versus intracellular signaling. J Clin Invest 2006, 116:623-626.

13. Bueno OF, Molkentin JD: Involvement of extracellular signal-regulated kinases 1/2 in cardiac hypertrophy and cell death. Circ Res 2002, 91:776-781.

14. Krebs HA: Rate control of the tricarboxylic acid cycle. Adv Enzyme Regul 1970, 8:335-353.

15. Correa PR, Kruglov EA, Thompson M, Leite MF, Dranoff JA, Nathanson MH: Succinate is a paracrine signal for liver damage. J Hepatol 2007, 47:262-269.

16. Blennow G, Folbergrova J, Nilsson B, Siesjo BK: Cerebral metabolic and circulatory changes in the rat during sustained seizures induced by DL-homocysteine. Brain Res 1979, 179:129-146.

17. Fedotcheva NI, Sokolov AP, Kondrashova MN: Nonezymatic formation of succinate in mitochondria under oxidative stress. Free Radic Biol Med 2006, 41:56-64.

18. Katsura K, Folbergrova J, Siesjo BK: Changes in labile energy metabolites, redox state and intracellular $\mathrm{pH}$ in postischemic brain of normo- and hyperglycemic rats. Brain Res 1996, 726:57-63.

19. Ekholm A, Katsura K, Kristian T, Liu M, Folbergrova J, Siesjo BK: Coupling of cellular energy state and ion homeostasis during recovery following brain ischemia. Brain Res 1993, 604:185-191.

20. Folbergrova J, Ljunggren B, Norberg K, Siesjo BK: Influence of complete ischemia on glycolytic metabolites, citric acid cycle intermediates, and associated amino acids in the rat cerebral cortex. Brain Res 1974, 80:265-279.

21. He W, Miao FJ, Lin DC, Schwandner RT, Wang Z, Gao J, Chen JL, Tian H, Ling L: Citric acid cycle intermediates as ligands for orphan G-proteincoupled receptors. Nature 2004, 429:188-193.

22. Aguiar CJ, Andrade VL, Gomes ER, Alves MN, Ladeira MS, Pinheiro AC, Gomes DA, Almeida AP, Goes AM, Resende RR, Guatimosim S, Leite MF: Succinate modulates $\mathrm{Ca}(2+)$ transient and cardiomyocyte viability through PKA-dependent pathway. Cell Calcium 2010, 47:37-46.

23. Robben JH, Fenton RA, Vargas SL, Schweer H, Peti-Peterdi J, Deen PM, Milligan G: Localization of the succinate receptor in the distal nephron and its signaling in polarized MDCK cells. Kidney Int 2009, 76:1258-1267.

24. Cannon RO III: Does coronary endothelial dysfunction cause myocardial ischemia in the absence of obstructive coronary artery disease? Circulation 1997, 96:3251-3254.

25. Varnava AM, Elliott PM, Mahon N, Davies MJ, McKenna WJ: Relation between myocyte disarray and outcome in hypertrophic cardiomyopathy. Am J Cardiol 2001, 88:275-279.

26. Lavoie $J L$, Sigmund $C D$ : Minireview: overview of the renin-angiotensin system-an endocrine and paracrine system. Endocrinology 2003, 144:2179-2183.

27. Derosa G, Maffioli P: Assessment and management of left ventricular hypertrophy in Type 2 diabetes patients with high blood pressure. Expert Rev Cardiovasc Ther 2013, 11:719-728.

28. Cuspidi C, Rescaldani M, Sala C, Negri F, Grassi G, Mancia G: Prevalence of electrocardiographic left ventricular hypertrophy in human hypertension: an updated review. J Hypertens 2012, 30:2066-2073.

29. Zhenfeng Z, Huilan S, Junya J, Dong L, Shan L: A systematic review and meta-analysis of candesartan and losartan in the management of essential hypertension. J Renin Angiotensin Aldosterone Syst 2011, 12:365-374.

30. Vargas SL, Toma I, Kang JJ, Meer EJ, Peti-Peterdi J: Activation of the succinate receptor GPR91 in macula densa cells causes renin release. J Am Soc Nephrol 2009, 20:1002-1011.

31. Hu J, Wu Q, Li T, Chen Y, Wang S: Inhibition of high glucose-induced VEGF release in retinal ganglion cells by RNA interference targeting G protein-coupled receptor 91. Exp Eye Res 2013, 109:31-39.
32. Kehat I, Davis J, Tiburcy M, Accornero F, Saba-El-Leil MK, Maillet M, York AJ, Lorenz JN, Zimmermann WH, Meloche S, Molkentin JD: Extracellular signal-regulated kinases 1 and 2 regulate the balance between eccentric and concentric cardiac growth. Circ Res 2011, 108:176-183.

33. Bers DM, Despa S, Bossuyt J: Regulation of $\mathrm{Ca} 2+$ and $\mathrm{Na}+$ in normal and failing cardiac myocytes. Ann N Y Acad Sci 2006, 1080:165-177.

34. Samuels ML, Weber MJ, Bishop JM, McMahon M: Conditional transformation of cells and rapid activation of the mitogen-activated protein kinase cascade by an estradiol-dependent human raf-1 protein kinase. Mol Cell Biol 1993, 13:6241-6252.

35. Traverse $S$, Cohen P: Identification of a latent MAP kinase kinase kinase in PC12 cells as B-raf. FEBS Lett 1994, 350:13-18.

36. Alessi DR, Cuenda A, Cohen P, Dudley DT, Saltiel AR: PD 098059 is a specific inhibitor of the activation of mitogen-activated protein kinase kinase in vitro and in vivo. J Biol Chem 1995, 270:27489-27494.

37. Chang S, McKinsey TA, Zhang CL, Richardson JA, Hill JA, Olson EN: Histone deacetylases 5 and 9 govern responsiveness of the heart to a subset of stress signals and play redundant roles in heart development. Mol Cell Biol 2004, 24:8467-8476.

38. Kranias EG, Bers DM: Calcium and cardiomyopathies. Subcell Biochem 2007, 45:523-537.

39. Vila-Petroff M, Mundina-Weilenmann C, Lezcano N, Snabaitis AK, Huergo MA, Valverde CA, Avkiran M, Mattiazzi A: $\mathrm{Ca}(2+) /$ calmodulin-dependent protein kinase II contributes to intracellular $\mathrm{pH}$ recovery from acidosis via $\mathrm{Na}(+) / \mathrm{H}(+)$ exchanger activation. J Mol Cell Cardiol 2010, 49:106-112.

40. Sadagopan N, Li W, Roberds SL, Major T, Preston GM, Yu Y, Tones MA: Circulating succinate is elevated in rodent models of hypertension and metabolic disease. Am J Hypertens 2007, 20:1209-1215.

41. Molkentin JD, Lu JR, Antos CL, Markham B, Richardson J, Robbins J, Grant SR, Olson EN: A calcineurin-dependent transcriptional pathway for cardiac hypertrophy. Cell 1998, 93:215-228.

42. Komuro I, Yazaki Y: Control of cardiac gene expression by mechanical stress. Annu Rev Physiol 1993, 55:55-75.

43. Lorenz K, Schmitt JP, Vidal M, Lohse MJ: Cardiac hypertrophy: targeting Raf/MEK/ERK1/2-signaling. Int J Biochem Cell Biol 2009, 41:2351-2355.

44. Hakak Y, Lehmann-Bruinsma K, Phillips S, Le T, Liaw C, Connolly DT, Behan DP: The role of the GPR91 ligand succinate in hematopoiesis. J Leukoc Biol 2009, 85:837-843.

45. Maier LS, Bers DM, Brown JH: Calmodulin and Ca2+/calmodulin kinases in the heart - physiology and pathophysiology. Cardiovasc Res 2007, 73:629-630.

46. Bossuyt J, Helmstadter K, Wu X, Clements-Jewery H, Haworth RS, Avkiran M, Martin JL, Pogwizd SM, Bers DM: Ca2+/calmodulin-dependent protein kinase Ildelta and protein kinase $D$ overexpression reinforce the histone deacetylase 5 redistribution in heart failure. Circ Res 2008, 102:695-702.

47. Sanna B, Bueno OF, Dai YS, Wilkins BJ, Molkentin JD: Direct and indirect interactions between calcineurin-NFAT and MEK1-extracellular signalregulated kinase $1 / 2$ signaling pathways regulate cardiac gene expression and cellular growth. Mol Cell Biol 2005, 25:865-878.

48. Liang Q, Bueno OF, Wilkins BJ, Kuan CY, Xia Y, Molkentin JD: C-Jun Nterminal kinases (JNK) antagonize cardiac growth through cross-talk with calcineurin-NFAT signaling. EMBO J 2003, 22:5079-5089.

49. Braz JC, Bueno OF, Liang Q, Wilkins BJ, Dai YS, Parsons S, Braunwart J, Glascock BJ, Klevitsky R, Kimball TF, Hewett TE, Molkentin JD: Targeted inhibition of p38 MAPK promotes hypertrophic cardiomyopathy through upregulation of calcineurin-NFAT signaling. J Clin Invest 2003, 111:1475-1486.

50. Antos CL, McKinsey TA, Frey N, Kutschke W, McAnally J, Shelton JM, Richardson JA, Hill JA, Olson EN: Activated glycogen synthase-3 beta suppresses cardiac hypertrophy in vivo. Proc Natl Acad Sci U S A 2002, 99:907-912.

51. Yang L, Yu D, Fan HH, Feng Y, Hu L, Zhang WY, Zhou K, Mo XM: Triggering the succinate receptor GPR91 enhances pressure overload-induced right ventricular hypertrophy. Int J Clin Exp Pathol 2014, 7:5415-5428.

52. Montano MM, Desjardins $C L$, Doughman $Y Q$, Hsieh $Y H$, Hu Y, Bensinger HM, Wang C, Stelzer JE, Dick TE, Hoit BD, Chandler MP, Yu X, Watanabe M: Inducible re-expression of HEXIM1 causes physiological cardiac hypertrophy in the adult mouse. Cardiovasc Res 2013, 99:74-82.

53. Zois NE, Bartels ED, Hunter I, Kousholt BS, Olsen LH, Goetze JP: Natriuretic peptides in cardiometabolic regulation and disease. Nat Rev Cardiol 2014, 11:403-412. 
54. Kato K, Matsubara T, Sakamoto N: Correlation between myocardial blood flow and tissue succinate during acute ischemia. Nagoya J Med Sci 1994, 57:43-50.

55. Rotstein OD, Pruett $T L$, Fiegel VD, Nelson RD, Simmons RL: Succinic acid, a metabolic by-product of Bacteroides species, inhibits polymorphonuclear leukocyte function. Infect Immun 1985, 48:402-408.

56. Rubic T, Lametschwandtner G, Jost S, Hinteregger S, Kund J, CarballidoPerrig N, Schwärzler C, Junt T, Voshol H, Meingassner JG, Mao X, Werner G, Rot A, Carballido JM: Triggering the succinate receptor GPR91 on dendritic cells enhances immunity. Nat Immunol 2008, 9:1261-1269.

57. Zucker AR, Gondolesi GE, Abbott MA, Decker R, Rosengren SS, Fishbein TM: Liver-intestine transplant from a pediatric donor with unrecognized mitochondrial succinate cytochrome $\mathrm{C}$ reductase deficiency. Transplantation 2005, 79:356-358.

58. Davili Z, Johar S, Hughes C, Kveselis D, Hoo J: Succinate dehydrogenase deficiency associated with dilated cardiomyopathy and ventricular noncompaction. Eur J Pediatr 2007, 166:867-870.

59. Guatimosim S, Amaya MJ, Guerra MT, Aguiar CJ, Goes AM, Gomez-Viquez NL, Rodrigues MA, Gomes DA, Martins-Cruz J, Lederer WJ, Leite MF: Nuclear Ca2+ regulates cardiomyocyte function. Cell Calcium 2008, 44:230-242.

60. Guatimosim S, Dilly K, Santana LF, Saleet JM, Sobie EA, Lederer WJ: Local Ca $(2+)$ signaling and $\mathrm{EC}$ coupling in heart: $\mathrm{Ca}(2+)$ sparks and the regulation of the $[\mathrm{Ca}(2+)](\mathrm{i})$ transient. J Mol Cell Cardiol 2002, 34:941-950.

61. Arantes LA, Aguiar CJ, Amaya MJ, Figueiro NC, Andrade LM, Rocha-Resende C, Resende RR, Franchini KG, Guatimosim S, Leite MF: Nuclear inositol 1,4,5-trisphosphate is a necessary and conserved signal for the induction of both pathological and physiological cardiomyocyte hypertrophy. J Mol Cell Cardiol 2012, 53:475-486.

62. Ladeira MS, Andrade VA, Gomes ER, Aguiar CJ, Moraes ER, Soares JS, Silva EE, Lacerda RG, Ladeira LO, Jorio A, Lima P, Leite MF, Resende RR, Guatimosim S: Highly efficient siRNA delivery system into human and murine cells using single-wall carbon nanotubes. Nanotechnology 2010, 21:385101.

63. Higazi DR, Fearnley CJ, Drawnel FM, Talasila A, Corps EM, Ritter O, McDonald F, Mikoshiba K, Bootman MD, Roderick HL: Endothelin-1-stimulated InsP3-induced $\mathrm{Ca} 2+$ release is a nexus for hypertrophic signaling in cardiac myocytes. Mol Cell 2009, 33:472-482.

64. Zhang G, Teggatz EG, Zhang AY, Koeberl MJ, Yi F, Chen L, Li PL: Cyclic ADP ribose-mediated $\mathrm{Ca} 2+$ signaling in mediating endothelial nitric oxide production in bovine coronary arteries. Am J Physiol Heart Circ Physiol 2006, 290:H1172-H1181.

65. Prada P, Okamoto MM, Furukawa LN, Machado UF, Heimann JC, Dolnikoff MS: High- or low-salt diet from weaning to adulthood: effect on insulin sensitivity in Wistar rats. Hypertension 2000, 35:424-429.

66. Matsusaka H, Ide T, Matsushima S, Ikeuchi M, Kubota T, Sunagawa K, Kinugawa S, Tsutsui H: Targeted deletion of p53 prevents cardiac rupture after myocardial infarction in mice. Cardiovasc Res 2006, 70:457-465.

67. Purushotham G, Madhumohan K, Anwaruddin M, Nagarajaram H, Hariram V, Narasimhan C, Bashyam MD: The MYH7 p.R787H mutation causes hypertrophic cardiomyopathy in two unrelated families. Exp Clin Cardiol 2010, 15:e1-e4.

68. Oliveira AG, Coelho PH, Guedes FD, Mahecha GA, Hess RA, Oliveira CA: 5alpha-Androstane-3beta,17beta-diol (3beta-diol), an estrogenic metabolite of 5alpha-dihydrotestosterone, is a potent modulator of estrogen receptor ERbeta expression in the ventral prostrate of adult rats. Steroids 2007, 72:914-922.

69. Ren L, Yang C, Peng Y, Li F, Li YH, Zheng H: Application of a high performance liquid chromatography-tandem mass spectrometry method for determination of buflomedil in human plasma for a bioequivalence study. J Chromatogr B Analyt Technol Biomed Life Sci 2013, 935:41-46.

70. Marques FD, Ferreira AJ, Sinisterra RD, Jacoby BA, Sousa FB, Caliari MV, Silva GA, Melo MB, Nadu AP, Souza LE, Irigoyen MC, Almeida AP, Santos RA: An oral formulation of angiotensin-(1-7) produces cardioprotective effects in infarcted and isoproterenol-treated rats. Hypertension 2011, 57:477-483.
71. Marques FD, Melo MB, Souza LE, Irigoyen MC, Sinisterra RD, de Sousa FB, Savergnini SQ, Braga VB, Ferreira AJ, Santos RA: Beneficial effects of long-term administration of an oral formulation of Angiotensin-(1-7) in infarcted rats. Int J Hypertens 2012, 2012:795452.

72. Gava E, de Castro CH, Ferreira AJ, Colleta H, Melo MB, Alenina N, Bader M, Oliveira LA, Santos RA, Kitten GT: Angiotensin-(1-7) receptor Mas is an essential modulator of extracellular matrix protein expression in the heart. Regul Pept 2012, 175:30-42.

73. Gavioli M, Lara A, Almeida PW, Lima AM, Damasceno DD, Rocha-Resende C, Ladeira M, Resende RR, Martinelli PM, Melo MB, Brum PC, Fontes MA, Souza Santos RA, Prado MA, Guatimosim S: Cholinergic signaling exerts protective effects in models of sympathetic hyperactivity-induced cardiac dysfunction. PLOS One 2014, 9:e100179.

\section{Submit your next manuscript to BioMed Central and take full advantage of:}

- Convenient online submission

- Thorough peer review

- No space constraints or color figure charges

- Immediate publication on acceptance

- Inclusion in PubMed, CAS, Scopus and Google Scholar

- Research which is freely available for redistribution

Submit your manuscript at www.biomedcentral.com/submit
C) BioMed Central 